\title{
Targeted therapies in renal cell cancer: recent developments in imaging
}

\author{
Astrid A. M. van der Veldt • Martijn R. Meijerink • \\ Alfons J. M. van den Eertwegh • Epie Boven
}

Received: 21 April 2010 /Accepted: 24 June 2010 /Published online: 14 July 2010

(C) The Author(s) 2010. This article is published with open access at Springerlink.com

\begin{abstract}
Targeted therapy has significantly improved the perspectives of patients with metastatic renal cell cancer (mRCC). Frequently, these new molecules cause disease stabilization rather than substantial tumor regression. As treatment options expand with the growing number of targeted agents, there is an increasing need for surrogate markers to early assess tumor response. Here, we review the currently available imaging techniques and response evaluation criteria for the assessment of tumor response in mRCC patients. For computed tomography (CT), different criteria are discussed including the Response Evaluation Criteria in Solid Tumors (RECIST), the Choi criteria, the modified Choi criteria, and the size and attenuation CT (SACT) criteria. Functional imaging modalities are discussed, such as dynamic contrast-enhanced CT (DCE-CT), dynamic contrast-enhanced magnetic resonance imaging (DCE-MRI), dynamic contrast-enhanced ultrasonography (DCE-US), and positron emission tomography (PET).
\end{abstract}

A. A. M. van der Veldt $(\triangle)$

Department of Nuclear Medicine \& PET Research,

VU University Medical Center,

De Boelelaan 1117,

1081 HV Amsterdam, The Netherlands

e-mail: aam.vanderveldt@vumc.nl

M. R. Meijerink

Department of Radiology,

VU University Medical Center,

De Boelelaan 1117,

1081 HV Amsterdam, The Netherlands

\author{
A. J. M. van den Eertwegh • E. Boven \\ Department of Medical Oncology, \\ VU University Medical Center, \\ De Boelelaan 1117
}

1081 HV Amsterdam, The Netherlands
Keywords Imaging $\cdot$ Renal cell cancer Response evaluation · Targeted therapy

\section{Introduction}

Renal cell carcinoma (RCC) is the thirteenth most common cancer worldwide, accounting for more than 208,000 new diagnoses and 102,000 deaths per year [1]. Approximately one third of patients present with metastatic disease at the time of diagnosis. In addition, about $30 \%$ of all other patients will develop metastases at a later stage of their disease. For decades, the treatment options for patients with metastatic renal cell cancer (mRCC) have been very limited, as RCC in general is not sensitive to chemotherapy. Since the early 1990 's, cytokine-based therapy consisting of interferon- $\alpha$ and/or interleukin-2 represented the only approach for systemic therapy of mRCC [2]. Although some patients may obtain long-lasting complete remissions upon cytokine therapy, responses in most mRCC patients are modest. In the past 5 years, molecular therapy has shown relevant efficacy in $\mathrm{mRCC}$, providing new hope for mRCC patients [3]. Currently, targeted agents have replaced immunotherapy with cytokines in the majority of mRCC cases.

Increasing knowledge of the underlying biology of RCC, and more specifically, the clear cell subtype, has identified interesting signaling pathways for targeted therapy. Sixty percent of clear cell carcinomas, a subtype accounting for $75 \%$ of all RCC, appear to contain an inactivated von Hippel-Lindau $(V H L)$ tumor suppressor gene. Alterations in the $V H L$ gene cause elevated protein levels of hypoxiainducible factor- $1 \alpha$ (HIF- $1 \alpha$, which upregulates vascular endothelial growth factor (VEGF) and platelet-derived growth factor (PDGF) genes and proteins [4]. Consequent- 
ly, the overexpression of these growth factors results in tumor angiogenesis [5] and extensive vascularization of RCC. Therefore, tumor angiogenesis has become an important focus of targeted therapy for RCC. The main classes of targeted agents for RCC are small molecules directed against receptor tyrosine kinases and monoclonal antibodies, both inhibiting signaling via the VEGF route.

Several antiangiogenic drugs, including bevacizumab [6], sorafenib [7], sunitinib [8], axitinib [9, 10], and pazopanib [11] have demonstrated significant efficacy in mRCC. In a phase III clinical trial in $\mathrm{mRCC}$, a combination of interferon- $\alpha$ with bevacizumab, the neutralizing antibody of VEGF, improved progression-free survival (PFS) with almost 5 months as compared to interferon- $\alpha$ alone [12]. Sunitinib, sorafenib, axitinib, and pazopanib are oral tyrosine kinase inhibitors (TKIs) of multiple receptors (R), including VEGFRs and PDGFRs. Although these TKIs have an overlapping mechanism of action, distinct differences are based on binding characteristics and their capacity to inhibit other targets. In comparison with placebo, sorafenib improved PFS in cytokine-pretreated mRCC with almost 3 months [7]. Sunitinib has demonstrated a significantly prolonged PFS (11 versus 5 months) as well as a higher objective response rate as compared with interferon- $\alpha$ (best tumor response $47 \%$ versus $12 \%$ ) in treatment-naive mRCC patients [13]. In addition, pazopanib significantly improved PFS and objective response rate as compared to placebo in a patient population consisting of treatment-naive and cytokine-pretreated patients (median PFS, 9 months versus 4 months; objective response rate, $30 \%$ versus $3 \%$ ) [11].

Besides inhibition of VEGF signaling, the mammalian target of rapamycin (mTOR) is another important therapeutic target in RCC, although its mechanisms of activation are not yet fully understood. mTOR may play a role in the development of RCC and is associated with elevated HIF activity [14]. mTOR inhibitors seem to down-regulate HIF activity primarily when the mTOR pathway is abnormally activated $[15,16]$. Temsirolimus and everolimus as inhib- itors of the mTOR pathway have demonstrated significant antitumor activity in RCC. Temsirolimus prolonged the overall survival (OS) in poor-risk mRCC patients as compared to interferon- $\alpha$ (11 months versus 7 and 8 months for, respectively, single-agent temsirolimus versus singleagent interferon- $\alpha$ and the combination) [17], whereas everolimus improved PFS as compared to placebo in patients with advanced RCC who had failed treatment with either sorafenib or sunitinib (4 months versus 2 months) [18].

Frequently, targeted molecules cause disease stabilization rather than substantial tumor regression in mRCC patients. For instance, treatment with sorafenib and temsirolimus is associated with low response rates $(\leq 10 \%)$, despite significant improvement of OS [7, 17]. Of interest, TKIs are known to induce early and extensive necrosis (Fig. 1) without a substantial decrease in tumor size [10, 19-22] and may even simulate progressive disease (PD), as treatment-induced necrosis may be accompanied by an increase in tumor size. Presently, response to targeted therapy is usually assessed by Response Evaluation Criteria in Solid Tumors (RECIST) [23], which is the most widely used measurement system in clinical trials. However, RECIST may underestimate objective responses during targeted therapy [24], as it is only based on the sum of the longest diameters of the appointed target lesions in the transversal plane [23] and does not account for other druginduced morphological changes.

Currently, several targeted agents have been approved for the treatment of mRCC that have significantly improved the perspectives of patients with mRCC. Nevertheless, treatments with these drugs fail in a number of these patients. In addition, targeted therapy is associated with a wide range of drug-induced toxicities that can be severe [24]. As treatment options expand with the growing number of targeted agents, there is an increasing need for surrogate markers to early assess tumor response. Here, we review the currently available imaging techniques and response evaluation criteria for the assessment of drug-induced
Fig. 1 Primary tumor at baseline $\mathbf{a}$ and after two cycles of sunitinib demonstrating a decrease in size as well as in attenuation due to the development of necrosis b [21]
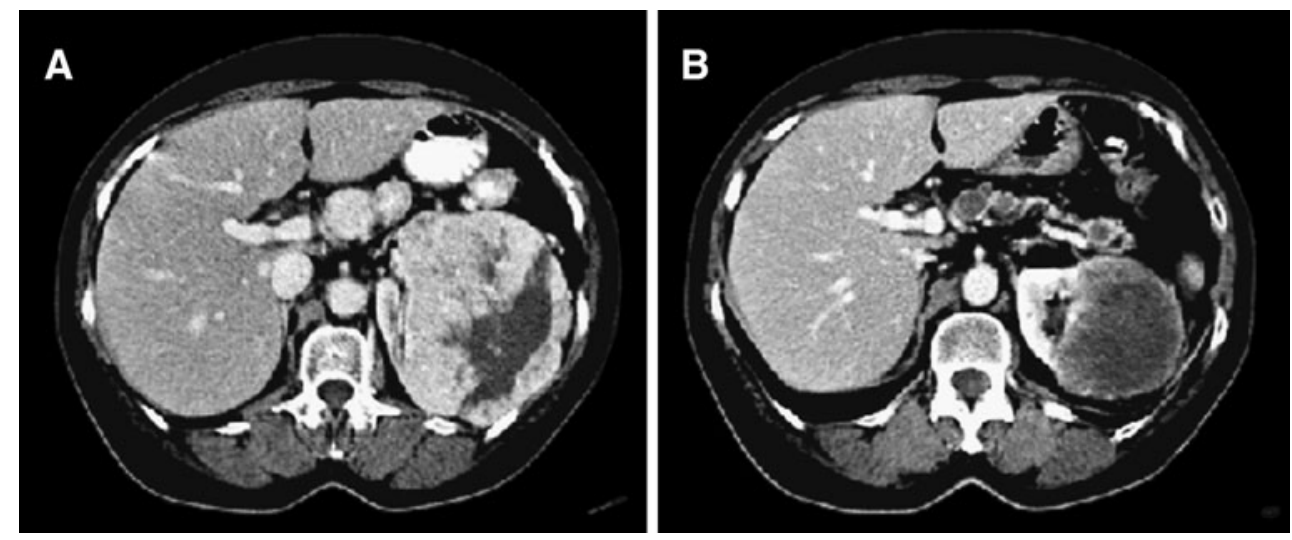
tumor response in $\mathrm{mRCC}$ patients. For computed tomography (CT), different criteria are discussed including RECIST, the Choi criteria, the modified Choi criteria, and the size and attenuation CT (SACT) criteria. In addition, functional imaging modalities are discussed, such as dynamic contrast-enhanced CT (DCE-CT), dynamic contrast-enhanced magnetic resonance imaging (DCEMRI), dynamic contrast-enhanced ultrasonography (DCEUS), and positron emission tomography (PET).

\section{Computed tomography}

Response evaluation criteria in solid tumors

Assessment of morphological changes, i.e., changes in tumor size burden, is an important evaluation method to determine the effect of anticancer drugs. Currently, RECIST is the most commonly used measurement system [23]. RECIST is a one-dimensional method and is based on the sum of the longest diameters of the appointed target lesions in the transversal plane. To determine tumor response accurately, target lesions ( $\geq 10 \mathrm{~mm}$ ) are usually identified on CT or magnetic resonance imaging (MRI). According to RECIST, chest X-ray may also be considered instead of CT if lesions are clearly defined, have a diameter of at least $20 \mathrm{~mm}$, and are surrounded by aerated lung. However, chest CT is preferred over chest $\mathrm{X}$-ray, as CT is more sensitive than X-ray, especially in identifying new lesions.

RECIST provides four classes to determine the objective tumor response for target lesions (Table 1). Briefly, complete response $(\mathrm{CR})$ is defined as disappearance of all target lesions, whereas a partial response (PR) requires a decrease in the sum of diameters of at least $30 \%$, taking as reference the sum of the diameters at baseline. The appearance of new lesions or at least a $20 \%$ increase in the sum of the diameters is classified as PD, taking as reference the smallest sum during treatment. When the changes in the sum of the diameters are not sufficient to qualify for PR or PD, the objective response is defined as stable disease (SD).

Recently, RECIST has been updated and version 1.1 has been introduced in the clinic [23]. As compared to the old version 1.0 [25], notable changes include a reduction in the number of target lesions to be assessed per patient (from a maximum of 10 to a maximum of 5) and per organ (from 5 to 2 per organ), a change in assessment of pathological lymph nodes (measurement of the longest axis has been changed into the shortest; nodes should have a short axis of $\geq 15 \mathrm{~mm}$ to be considered as measurable) and the clarification of disease progression in small tumor burden (a $5 \mathrm{~mm}$ absolute increase is now required).

Many studies have applied RECIST to determine response to targeted therapy in $\operatorname{mRCC}[7,8,18]$. Best response may take several months [8, 13], and is occasionally achieved up to 10 months after the start of treatment [22]. In a previous study in $55 \mathrm{mRCC}$ patients treated with sunitinib, $13 \%$ of patients had PR, $69 \%$ of patients had SD, and $18 \%$ of patients had PD at a median of 1.9 months after the start, but $18 \%$ of patients with initial SD reached a PR at later time-points (median time to PR: 3.9 months; range: 2.4-9.7 months) [22]. Therefore, with the use of RECIST at first evaluation in patients with SD it cannot be discriminated which patients will have PD at the next time-point in order to timely change the type of treatment, since some patients benefit from continued SD and some patients may even reach a PR.

Size variation for response evaluation

Since the expected effect of targeted agents in mRCC would be stabilization rather than substantial tumor regression, PR according to RECIST may not be accurate in the era of targeted therapy. Therefore, Thiam et al. [26] have attempted to determine a threshold for CT evaluation that best reflected treatment outcome. With PFS as the primary outcome, thresholds from $-45 \%$ to $+10 \%$ were tested in $334 \mathrm{mRCC}$ patients treated with sunitinib. A decrease of at least $10 \%$ in the sum of the longest diameters was identified as the most accurate threshold to distinguish responders ( $n$ =256) from non-responders $(n=78)$. Already during the first treatment cycle, $73 \%$ of patients reached a response according to the $-10 \%$ threshold, whereas only $19 \%$ of patients reached a PR according to RECIST $(\geq 30 \%$ decrease). After the second treatment cycle, the $-10 \%$ and $-30 \%$ thresholds were achieved in $93 \%$ en $64 \%$ of the patients. This study shows that responders can be earlier identified with the $-10 \%$ threshold than with the conventional threshold of $-30 \%$ according to RECIST.

\section{Contrast-enhanced computed tomography}

Impressive changes in tumor attenuation have been observed during targeted therapy as visualized by contrastenhanced CT. The contrast-enhancement on CT is directly related to tumor angiogenesis [27-29]. In metastases from RCC, higher pretreatment values of contrast-enhancement are associated with a higher response rate to targeted therapy consisting of either sunitinib or sorafenib [30], allowing prediction of outcomes of individual metastatic lesions before the start of targeted therapy. In addition, treatment-induced changes in tumor density are associated with response to therapy and the development of necrotic areas [31]. In contrast, the development of a marked central fill-in and new enhancement in homogeneously, hypoattenuating, non-enhancing RCC lesions are commonly seen at or just before the time of progression late in the 


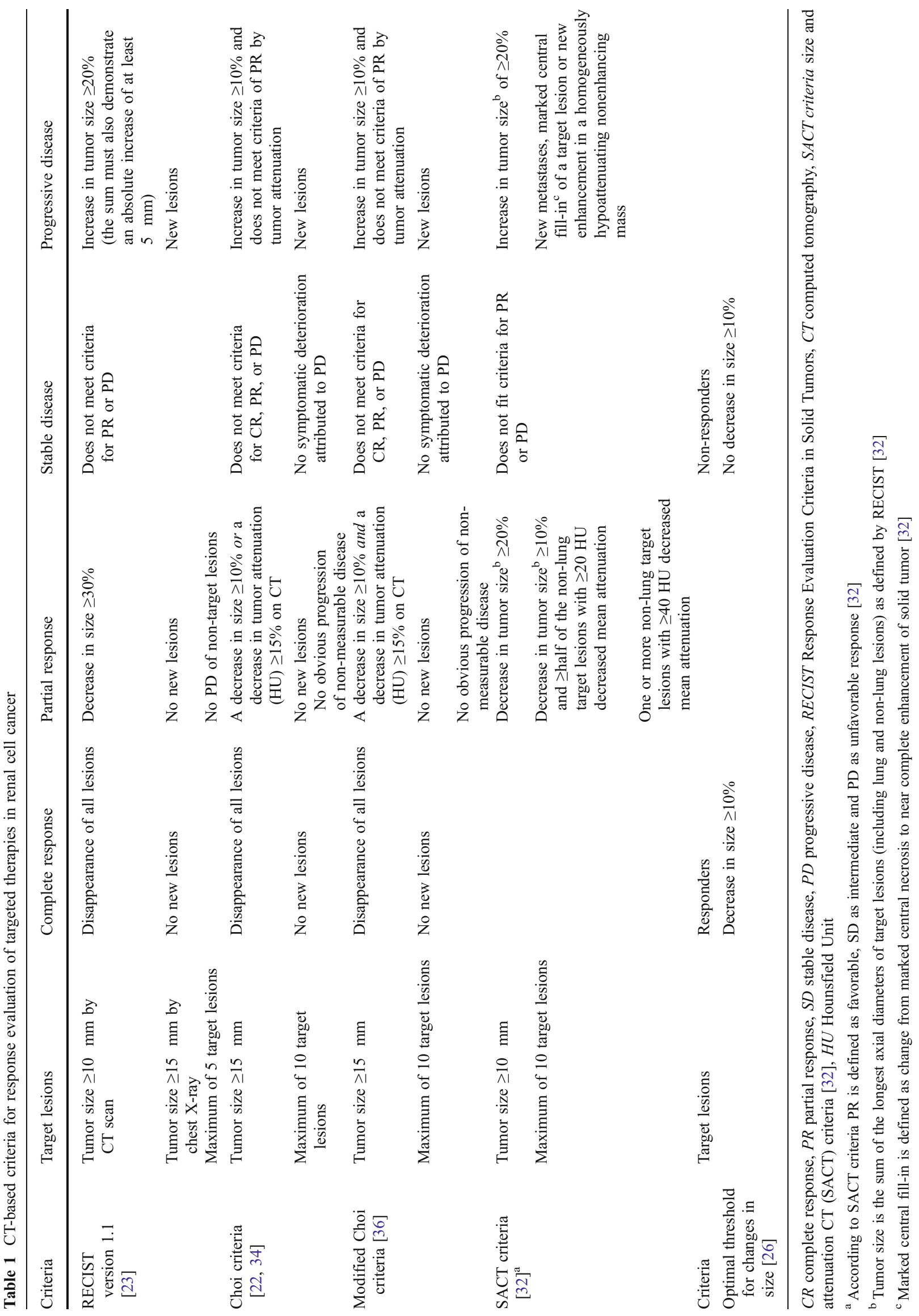


course of treatment [32], suggesting that an increase in contrast-enhancement may be associated with disease progression. Currently, three different response evaluation criteria that incorporate changes in contrast-enhancement have been investigated in mRCC patients: the Choi criteria, the modified Choi criteria, and the size and attenuation CT (SACT) criteria (Table 1).

\section{Choi criteria}

Using contrast-enhanced CT scans, Choi et al. [33, 34] have developed new evaluation criteria to determine the efficacy of imatinib in patients with gastrointestinal stromal cell tumors (GIST). In patients with GIST, imatinib is known to induce extensive tumor necrosis that may be accompanied by an increase in tumor size and may even simulate PD [34]. The Choi criteria include changes in tumor attenuation expressed as Hounsfield Units (HU) on contrast-enhanced CT. The threshold for changes in tumor attenuation on CT is based on a decrease of the maximum standardized uptake value $\left(\mathrm{SUV}_{\text {max }}\right)$ of at least $70 \%$ as measured by positron emission tomography (PET) using 2-[ $\left.{ }^{18} \mathrm{~F}\right]$ fluoro-2-deoxyD-glucose ( $\left.\left[{ }^{18} \mathrm{~F}\right] \mathrm{FDG}\right)$. According to Choi et al. [33, 34], a $\mathrm{PR}$ is defined as $\mathrm{a} \geq 10 \%$ decrease in one-dimensional tumor size or a $\geq 15 \%$ decrease in tumor attenuation on contrastenhanced CT scan, while PD is defined as a $\geq 10 \%$ increase in size without meeting PR criteria by change in attenuation (Table 1). Lesions with a longest diameter $\geq 15 \mathrm{~mm}$ are eligible for measurements according to the Choi criteria. In imatinib-treated patients with GIST, the Choi criteria had a significantly better correlation with disease-specific survival than RECIST.

Recently, we have evaluated the Choi criteria in 55 mRCC patients who were treated with sunitinib [22]. During sunitinib treatment, the median tumor attenuation decreased from 66 to $47 \mathrm{HUs}$. According to the Choi criteria, $36(65 \%)$ patients achieved a PR, $6(11 \%)$ patients had SD and 13 (24\%) patients had PD at first evaluation. In 19 out of 36 responders, the achieved PR was only based on a decrease in tumor attenuation $\geq 15 \%$. Patients with a PR according to Choi criteria had a prolonged PFS and OS as compared to patients without a PR. At first evaluation, the Choi criteria had a significantly better predictive value for PFS and OS than RECIST. However, the predictive value of the Choi criteria was similar to that of RECIST at later time-points. The Choi criteria were not able to early identify patients with PD. Therefore, we concluded that the Choi criteria will not change the clinical management of mRCC patients treated with sunitinib.

The Choi criteria may be more useful to identify mRCC patients with PD during sorafenib treatment, as sorafenib is associated with extensive necrosis [35] and fewer patients have tumor response to sorafenib as compared to sunitinib
[32]. Two studies have described less favorable results for the use of the Choi criteria in comparison with RECIST in mRCC patients $[32,36]$. In these analyses, however, fewer mRCC patients were included [36], different TKIs were administered (sunitinib, sorafenib, and cediranib) [32, 36], lung lesions were excluded for attenuation measurements [32], and attenuation measurements were based on volumetric data instead of two-dimensional data acquired in most representative axial images [32].

\section{Modified Choi criteria}

Nathan et al. [36] have compared the Choi criteria with the modified Choi criteria in which changes in both size and attenuation of target lesions have to be calculated to define an objective response (Table 1). In that study, CT scans from $32 \mathrm{mRCC}$ patients who were treated with either sunitinib or cediranib were evaluated. Ten patients needed to be excluded from further analysis because of non contrast-enhanced CT scans due to renal impairment. Ultimately, 20 patients were evaluable of whom 5, 19, and 13 patients achieved a PR according to, respectively, RECIST, the Choi criteria, and the modified Choi criteria. The group concluded that the modified Choi criteria provided the best segregation of the median time-toprogression.

\section{Size and attenuation CT (SACT) criteria}

As a $\geq 10 \%$ decrease in tumor size or a $\geq 15 \%$ decrease in tumor attenuation is not necessarily associated with a prolonged PFS, the size and attenuation CT (SACT) criteria have been developed (Table 1) [32]. According to these criteria a favorable response is defined as a decrease in tumor size of $\geq 20 \%$ or a decrease in mean attenuation of $\geq 40 \mathrm{HU}$ in at least one non-lung target lesion. In case patients have a decrease in tumor size of $\geq 10 \%$ and a decrease in mean attenuation of $\geq 20 \mathrm{HU}$ in half of the non-lung target lesions, they are also classified as favorable responders. Patients have an unfavorable response in case of an increase in tumor size of $\geq 20 \%$ or the development of new lesions. Patients also have an unfavorable response in case of new enhancement in a homogeneously hypo-attenuating non-enhancing lesion or in case of a marked change from central necrosis to near complete enhancement of solid parts in the central area of the tumor. According to the SACT criteria, mean attenuation measurements are based on volumetric measurements. Lung lesions are not eligible because of inconsistent mean attenuation results from averaging between soft tissue and air. This is a potential limitation for the use of SACT criteria in $\mathrm{mRCC}$ patients as the lung is a common metastatic site. The use of absolute changes instead of percentage changes in tumor attenuation is a potential advantage of the SCAT 
criteria as compared to the Choi and the modified Choi criteria, since a $15 \%$ decrease in attenuation is reached early in lesions with low baseline values and may therefore result in less accurate measurements.

Limitations of contrast-enhanced measurements in RCC

Although incorporation of changes in tumor attenuation appears to be valuable for response assessment, several limitations should be mentioned for its use in $\mathrm{mRCC}$ patients who are treated with targeted agents. A series of requirements have to be taken into account, such as identical scanning protocols and the same timing of intravenous contrast (IV) between the subsequent $\mathrm{CT}$ scans, as slightly different phases in IV contrast may result in incorrect changes in lesion attenuation. It should also be considered that targeted agents may affect the cardiac output [37], because of which the distribution of IV contrast may change during treatment despite the use of an identical scanning protocol. Additionally, contrast-enhanced CT scanning may not be possible in a number of mRCC patients, since administration of IV contrast may be contraindicated in case of an impaired renal function [36].

\section{Dynamic contrast-enhanced CT (DCE-CT)}

As the measurement of contrast-enhancement on CT does not provide quantitative measurement of kinetic variables, such as the contribution of flow, dynamic imaging by CT may be more appropriate to evaluate these variables during targeted therapy. Dynamic contrast-enhanced CT (DCE-CT or $\mathrm{CTP}$ ) is a functional perfusion $\mathrm{CT}$ that provides estimations of the tissue perfusion parameters blood flow (BF), blood volume (BV), mean transit time (MTT), and capillary permeability surface area (PS). After IV injection of a freely diffusible iodine-based contrast agent, dynamic CT scanning is performed of a selected field of view in which the lesion of interest is localized. Using CT perfusion software, the tissue perfusion parameters (BF, BV, MTT, and PS) can be estimated.

Few clinical studies have used DCE-CT to measure response to therapy [38-41] and none thus far in mRCC patients receiving targeted therapy. In various solid tumors, DCE-CT has shown a reduction in perfusion during antiangiogenic therapy $[38,39]$. In 12 patients with colorectal cancer, DCE-CT demonstrated anti-vascular effects within 7 days after administration of bevacizumab [38].

In 33 bevacizumab-treated patients with hepatocellular carcinoma, DCE-CT has been performed at baseline and on days 10-12 [41]. In 23 evaluable patients, significant decreases in $\mathrm{BF}, \mathrm{BV}$, and PS were observed, while an increase in MTT was calculated. In 21 hepatocellular carcinoma patients DCE-CT could be related to clinical outcome. Patients with PD had lower baseline MTT values and a higher percent increase following bevacizumab administration than those with SD or PR. As enhancement parameters of dynamic CT correlate with microvessel density (MVD) in RCC [42], DCE-CT may have additional value for early assessment of tumor response to targeted therapy. A disadvantage of DCE-CT is the high radiation burden, which limits its serial use for repeated response assessments.

\section{Magnetic resonance imaging (MRI)}

Dynamic contrast-enhanced MRI (DCE-MRI)

DCE-MRI is widely used in the diagnosis and staging of cancer and is emerging as a promising method for monitoring tumor response to targeted therapy [43, 44]. Quantitative $T_{1}$-weighted images of the microvasculature are obtained by tracking the pharmacokinetics of an IV bolus of a gadolinium-containing contrast agent, which is freely diffusible between the intravascular and the extracellular extravascular space. Gadolinium ions are paramagnetic and shorten the $T_{1}$-relaxation times in tissue water by interaction with nearby hydrogen nuclei. In a $\mathrm{T}_{1}$-weighted DCE-MRI, the tumor enhancement over time reflects the delivery of the gadolinium contrast into the tumor tissue. Although DCE-MRI imaging protocols differ, three types of imaging data are usually acquired. The first images are used for localization of the tumor. Thereafter, sequences are acquired that are used to calculate the baseline $T_{1}$-values which are necessary for the analysis. At last, dynamic imaging data are acquired for about 5-10 $\mathrm{min}$ after gadolinium injection [44].

Data analysis of DCE-MRI is complex, as the obtained variables are mainly dependent on the acquisition protocol and the method for data analysis [45]. In addition, no consensus has been reached on the kinetic model to be used for the analysis of DCE-MRI data to measure the efficacy of targeted agents. The various acquisition and analysis methods have considerable influence on the interpretation of the obtained variables and their value as surrogate end-points for targeted therapy. For pharmacokinetic modeling of contrast agent uptake, a compartment model is commonly used to estimate three physiological parameters including the volume transfer constant $K^{\text {trans }}$ between the blood plasma and extravascular extracellular space (EES) $\left(\mathrm{min}^{-1}\right)$, the volume of EES per unit volume of tissue and the flux rate constant between EES and plasma $\left(\mathrm{min}^{-1}\right)$ (Fig. 2). A change in $K^{\text {trans }}$ of $>40 \%$ is usually considered a true difference caused by drug effect [45]. In addition, the area 
under the gadolinium concentration curve is another frequently used parameter to determine treatment effects.

In a number of clinical studies in solid tumors, DCEMRI has been applied to monitor early response to targeted therapy [46-48], particularly in mRCC [49-52]. In a phase II trial in $17 \mathrm{mRCC}$ patients, sorafenib treatment induced a large decline in $K^{\text {trans }}$ of $60.3 \%$ [49]. The percentage decline of $K^{\text {trans }}$ and the change in tumor size by CT scan were significantly associated with PFS [49]. Additionally, high tumor $K^{\text {trans }}$ before treatment was also significantly associated with improved PFS [49]. In another DCE-MRI study in $44 \mathrm{mRCC}$ patients, four weeks after initiation of placebo, sorafenib $200 \mathrm{mg} \times 2$ and sorafenib $400 \mathrm{mg} \times 2$, the mean $K^{\text {trans }} \log$ ratios had changed by, respectively, $+14 \%$, $-14 \%$ and $-24 \%$ [50]. The changes in $K^{\text {trans }}$ were not associated with PFS, but patients with a high $K^{\text {trans }}$ at baseline had a prolonged PFS. The association between a high $K^{\text {trans }}$ at baseline and a prolonged PFS is in line with the results of the study by Flaherty et al. [49]. Remarkably, the effects of sorafenib on DCE-MRI parameters appeared to be highly variable across the tumor regions of interest which suggests that a more detailed voxel-based analysis, such as parametric images, might be more useful to analyze sorafenib-treated RCC lesions.

\section{Arterial spin labeling (ASL) MRI}

ASL is an alternative for the measurement of tumor blood flow by MRI and requires no external tracers [53, 54]. Labeling of arterial blood is achieved by spatially selective inversion of the MRI signal of inflowing arterial blood. The MRI signal from inverted blood is made negative relative to uninverted blood. When the labeled blood with a negative signal enters the tumor lesion, it attenuates the signal from the image of that lesion. The difference between the labeled image and the control image without labeling gives a measure of blood flow. The ASL tracer is water and can consequently be considered as highly diffusible.

In $10 \mathrm{mRCC}$ patients treated with vatalanib, ASL MRI already showed changes in tumor blood flow at 1 month on treatment, while changes in size according to RECIST were only measured at 4 months [55]. ASL MRI demonstrated a

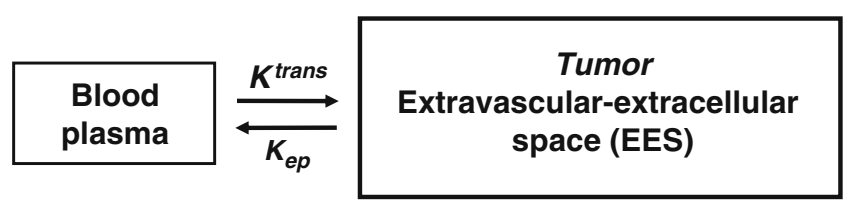

Fig. 2 A tracer kinetic model for the analysis of dynamic gadoliniumenhanced magnetic resonance imaging (MRI) is used to estimate 3 physiologic parameters: volume transfer constant $\left(K^{\text {trans }}\right)$ between blood plasma and extravascular extracellular space (EES), volume of EES per unit volume of tissue $\left(v_{e}\right)$, and flux rate constant between the EES and plasma, $\kappa_{e p}\left(\kappa_{e p}=K^{\text {trans }} / v_{e}\right)$ significant decrease in blood flow $(-42 \pm 22 \%)$ in $\mathrm{mRCC}$ patients with $\mathrm{SD}$ or PR, whereas patients with $\mathrm{PD}$ had a non-significant increase in tumor blood flow $(+25 \pm 3 \%)$. As ASL MRI does not involve administration of contrast medium, the technique provides the opportunity of frequently repeated measurements, particularly in RCC patients with impaired renal function [56], and can be applied to determine the optimal time-point for perfusion measurement during antiangiogenic treatment.

\section{Diffusion-weighted MRI (DW-MRI)}

DW-MRI is another alternative to contrast-enhanced MRI, as this technique does not require administration of contrast [57]. DW-MRI is sensitive to the random motion of water molecules and allows for non-invasive characterization of biological tissues on the basis of their water-diffusion properties [58]. Highly cellular tissues can be differentiated from acellular tissues, as diffusion of water molecules is reduced in the cellular area in comparison with that in the extracellular space. The degree of water diffusion within tissues, or the apparent diffusion coefficient (ADC) in $\mathrm{mm}^{2} \cdot \mathrm{s}^{-1}$, can be calculated by acquiring multiple images with different amplitudes or durations for the diffusionweighting gradients. Consequently, increased cellularity and decreased interstitial space result in restriction of water molecules and decreased ADC values. In tumors, DW-MRI can be used to differentiate highly cellular from acellular regions and to monitor changes in cellularity over time, which reflects tumor response to therapy [59-63]. In addition, ADC is a reproducible physical constant, which is independent of scanner, magnetic field and operator. However, there are some limitations with regard to the placement of regions of interest (ROI) on ADC maps caused by poor resolution, which results in partial volume effects.

In RCC, DW-MRI has been mainly evaluated for characterization of primary tumors [57, 64-68]. In these studies, ADC values of high-grade clear cell carcinomas were lower than those of low-grade clear cell carcinomas [66], whereas ADC values of non-clear cell carcinomas were higher than those of the clear cell subtype [64]. The experience with DW-MRI in monitoring of $\mathrm{mRCC}$ during treatment is limited [69] and studies are warranted to substantiate the use of DW-MRI as a biomarker for response to targeted therapy in mRCC.

\section{Dynamic contrast-enhanced ultrasonography (DCE-US)}

DCE-US is a functional imaging technique that can be used to detect microvessels and quantitatively assess tumor perfusion of solid tumors [70-72]. DCE-US requires Doppler ultrasound and a microbubble contrast agent, 
which enhances the vessel signal and enables detection of blood vessels with a diameter as small as $40 \mu \mathrm{m}$ [73]. The microbubbles remain in the intravascular compartment and are not subjected to extra-vascular diffusion. DCE-US provides both morphological and functional perfusion data. Semi-quantitative perfusion measurements can be obtained from the time-concentration curve. Quantitative data can be obtained by analyzing the replenishment kinetics directly after the sudden and local destruction of the phospholipidbased microbubbles that encapsulate an inert gas [74]. The quantitative analysis is performed on the contrast uptake curve in the tumor which is constructed from raw linear data [70]. Then 3 min of raw data are used for quantification in order to obtain seven parameters: peak intensity (PI), time to peak intensity (TPI), mean transit time (MTT), coefficient of wash-in slope, area under the total curve, area under the curve during the wash-in and area under the curve during the wash-out [70] (Fig. 3). Of these parameters, the slope of the time to peak intensity correlates with blood flow, whereas the peak intensity and area under the curve correlate with blood volume.

Thus far, a number of clinical trials with targeted agents have incorporated DCE-US for imaging of lesions and demonstrated that DCE-US parameters may be correlated with tumor response [75-78]. In mRCC patients, the usefulness of DCE-US was investigated during treatment with sunitinib [76, 79] and sorafenib [75, 78] (Fig. 4). In 38 mRCC patients treated with sunitinib, the ratio between DCE-US values at baseline and day 15 was significantly different in responders (PR according to RECIST) and nonresponders (no PR according to RECIST) for five out of seven DCE-US parameters: peak intensity (PI), area under the total curve, area under the wash-out, time to peak intensity, and slope of wash-in. In addition, the peak intensity and the slope of the wash-in were significantly associated with PFS [76]. An increase in the time to peak intensity $>29 \%$ and a decrease in the slope of the wash-in $>76 \%$ were associated with an increased PFS and OS [76]. In another DCE-US study, $30 \mathrm{mRCC}$ patients were treated with sorafenib or placebo [75]. At 3 weeks of therapy, good responders could be discriminated from non-responders based on the combination of a decrease in contrast uptake $>10 \%$ and stability or decrease in tumor volume [75].

Although various RCC lesions (e.g., liver metastases and abdominal lymph nodes) are accessible for DCE-US measurements, DCE-US cannot be used for aerated lesions in the lung, as ultrasound waves are disrupted by air or gas. This is a potential limitation for the use of DCE-US in mRCC, as the lung is a common metastastic site. Advantages of DCE-US, however, include the low costs, the low inter-operator variability [80], its ease of use, and the possibility to repeat the measurements without adverse effects, such as exposure to ionizing radiation. Currently,

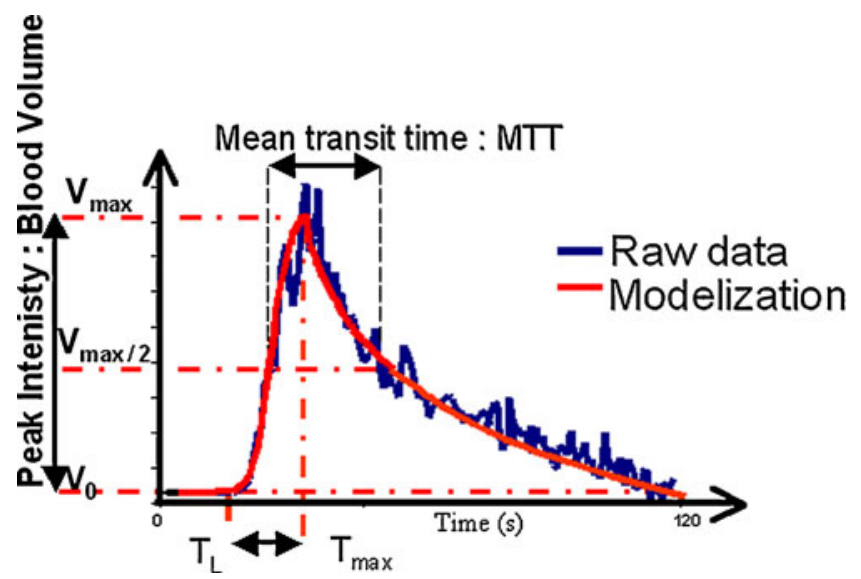

Fig. 3 Contrast uptake curve obtained by DCE-US. The slope of the time to peak intensity correlates with blood flow, whereas the peak intensity and area under the curve correlate with blood volume (reproduced with permission, (c) Springer-Verlag 2007 [70])

the feasibility of DCE-US in monitoring antiangiogenic treatment is evaluated in a French National Program in which 650 patients with different malignancies will be included and 4,800 examinations are planned [70]. DCEUS will be performed at baseline and after 1, 7 and 15 days and after 1 and 2 months, and then every 2 months. The results of this large national study in which 18 French institutions are involved may define the best DCE-US parameter and the best time-point to assess the efficacy of antiangiogenic treatment, and may reveal the best threshold to differentiate between responders and non-responders.

\section{Positron emission tomography (PET)}

2-[ $\left[{ }^{18}\right.$ F $]$ fluoro-2-deoxy-D-glucose $\left(\left[{ }^{18} \mathrm{~F}\right] \mathrm{FDG}\right)$

$\left[{ }^{18} \mathrm{~F}\right]$ FDG PET is an important functional imaging tool in oncology [81]. The use of $\left[{ }^{18} \mathrm{~F}\right] \mathrm{FDG}$ is based on the fact that malignant tumor cells have a high glucose metabolism and actively take up glucose and its analogue $\left[{ }^{18} \mathrm{~F}\right] \mathrm{FDG}$. The use of $\left[{ }^{18} \mathrm{~F}\right]$ FDG PET in patients with RCC is limited [82], since $\left[{ }^{18} \mathrm{~F}\right] \mathrm{FDG}$ PET has no major value for the detection of renal masses [83] or RCC metastases [84, 85]. As RCC has only a low potential for metabolizing glucose [86], a negative $\left[{ }^{18} \mathrm{~F}\right] \mathrm{FDG}$ PET does not rule out the presence of RCC. A positive $\left[{ }^{18} \mathrm{~F}\right] \mathrm{FDG}$ PET in RCC patients, however, is predictive for the presence of a RCC lesion [87, 88] and may complement anatomic imaging modalities, such as CT or may even be used in combination with CT [89].

When RCC is $\left[{ }^{18} \mathrm{~F}\right]$ FDG avid, $\left[{ }^{18} \mathrm{~F}\right]$ FDG PET can be applied to monitor the disease and may have additional value for response evaluation of targeted therapy [90-93]. In mRCC, a significant decrease of $\left[{ }^{18} \mathrm{~F}\right] \mathrm{FDG}$ uptake has been 


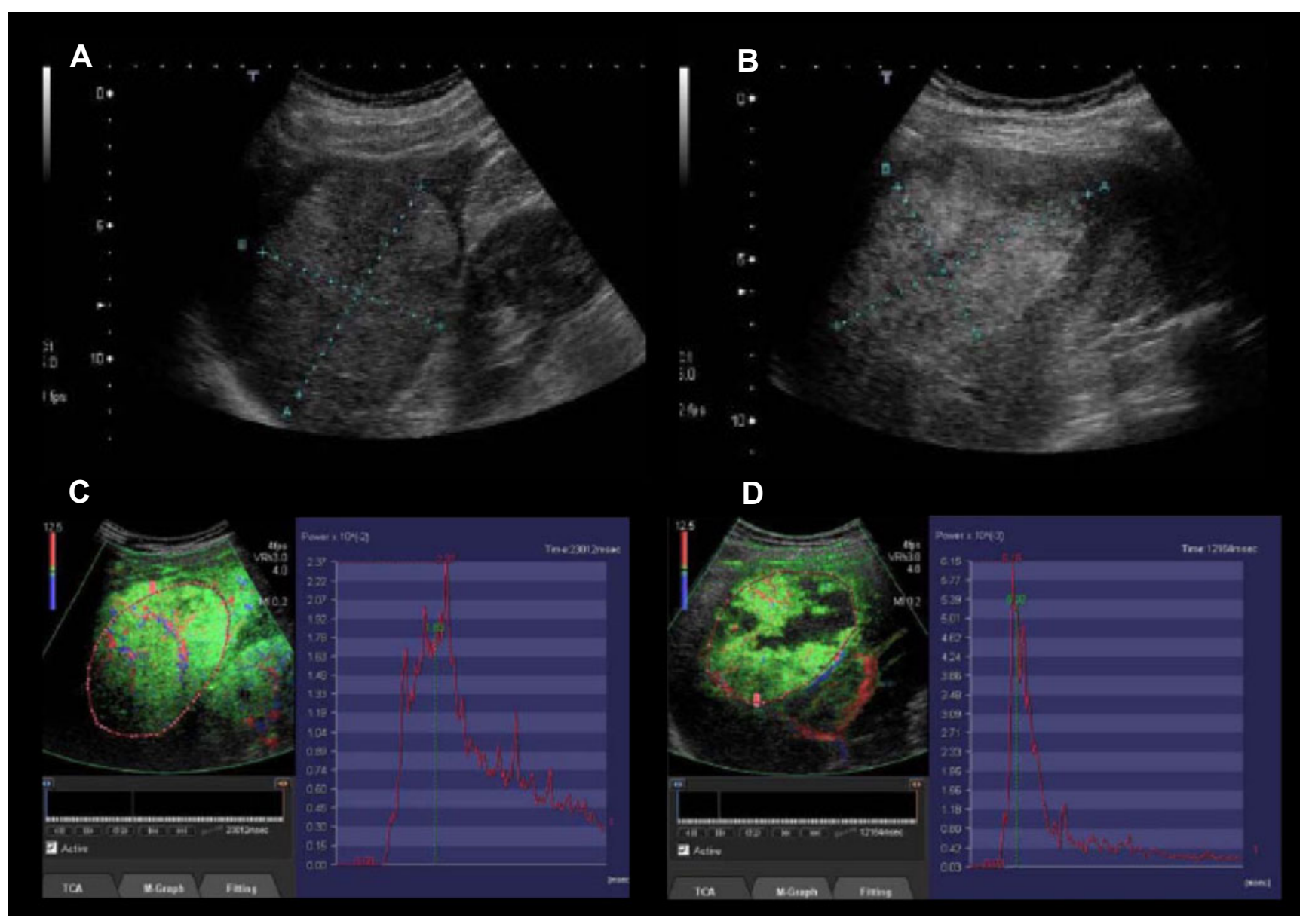

Fig. 4 An example of DCE-US in a patient with renal cell cancer treated with a combination of a mTOR inhibitor and bevacizumab. DCE-US of hepatic metastases before treatment (a, c) and on day 7 (b,

measured in patients treated with either sunitinib or sorafenib $[92,93]$. In a recent study, $12 \mathrm{mRCC}$ patients underwent $\left[{ }^{18} \mathrm{~F}\right]$ FDG PET to assess tumor response to sunitinib [93]. After the first treatment cycle, there was a decrease in the maximum standardized uptake value $\left(\mathrm{SUV}_{\max }\right)$ of $17 \%$ (range; $-59 \%$ to $+100 \%$ ), while the sum of the target lesions remained unchanged [93]. In two out of 12 patients, a nonsignificant decrease in $\mathrm{SUV}_{\max }$ was measured, along with a non-significant increase in tumor size which was associated with a decrease in tumor density on CT [93]. As both patients had a long PFS (335 and 455 days), these findings suggested that the increase in tumor size in these patients was associated with the development of necrosis instead of PD. In another study, combined $\left[{ }^{18} \mathrm{~F}\right] \mathrm{FDG}$ PET/CT has been applied for assessment of tumor response in $10 \mathrm{mRCC}$ patients treated with sorafenib [92]. After 1-2 months of sorafenib treatment, the mean and maximum $\left[{ }^{18} \mathrm{~F}\right] \mathrm{FDG}$ uptake in all lesions decreased to, respectively, $75 \%$ (range; $32-105 \%$ ) and $86 \%$ (range; $46-131 \%$ ) of the baseline value [92]. Sorafenib appeared to induce a heterogeneous decrease d) demonstrating necrosis. c and $\mathbf{d}$ represent the corresponding contrast uptake curves before treatment and on day 7 (reproduced with permission, (C) Springer-Verlag 2010 [72])

in $\left[{ }^{18} \mathrm{~F}\right] \mathrm{FDG}$ uptake in tumor lesions [92], suggesting that volumetric measurements may have additional value to determine tumor response in individual lesions. Both studies described above had performed $\left[{ }^{18} \mathrm{~F}\right] \mathrm{FDG}$ PET scanning after the first treatment cycle, but this technique may already be able to detect a metabolic response within 1 week as has been demonstrated for imatinib-treated GIST lesions [94, 95]. Indeed, an early metabolic response by $\left[{ }^{18} \mathrm{~F}\right] \mathrm{FDG}$ PET was reported within 2 weeks of therapy in a mRCC patient treated with semaxanib (SU5416) [90]. ${ }^{18}$ F]FDG PET has not yet been evaluated in mRCC patients on treatment with mTOR inhibitors, but early inhibition of $\left[{ }^{18} \mathrm{~F}\right] \mathrm{FDG}$ uptake has been noted in patients with non-small cell lung cancer who were treated with everolimus [96]. This suggests that $\left[{ }^{18} \mathrm{~F}\right]$ FDG PET may also be useful to assess metabolic response in $\mathrm{mRCC}$ patients treated with mTOR inhibitors.

Although the role of $\left[{ }^{18} \mathrm{~F}\right] \mathrm{FDG}$ PET for response evaluation of targeted therapy is expanding [92, 93, 96, 97], $\left[{ }^{18} \mathrm{~F}\right]$ FDG PET scanning is not incorporated in commonly used response evaluation criteria. According to 
RECIST, however, the use of $\left[{ }^{18} \mathrm{~F}\right] \mathrm{FDG}$ PET imaging is accepted as an adjunct to determination of progression [23]. The PET Criteria in Solid Tumors (PERCIST) version 1.0 has been proposed for metabolic tumor response assessment and serves as a starting point for PET-based response evaluation in clinical trials [98]. To ensure that PET images are acquired and interpreted optimally, $\left[{ }^{18} \mathrm{~F}\right] \mathrm{FDG}$ PET scans should be performed according to guidelines that provide a minimum standard for acquisition and require a common quality control and quality assurance [99].

Other tracers for positron emission tomography

Besides the most commonly used PET tracer $\left[{ }^{18} \mathrm{~F}\right] \mathrm{FDG}$, other PET tracers have been developed for use in patients with malignancies. The accumulation of the PET tracer $\left[{ }^{11} \mathrm{C}\right]$ acetate in tumor cells is related to the highly active lipid metabolism in the cell membrane associated with tumor growth. $\left[{ }^{11} \mathrm{C}\right]$ acetate is channeled into the tricarboxylic acid cycle via acetyl coenzyme A and then incorporated into the cell membrane's phospholipids. In malignancies, high uptake of $\left[{ }^{11} \mathrm{C}\right]$ acetate was first reported in $\operatorname{RCC}[100,101]$. Currently, $\left[{ }^{11} \mathrm{C}\right]$ acetate PET has been introduced as a new modality for imaging prostate cancer and its metastases [102]. In a RCC case report, uptake of $\left[{ }^{11} \mathrm{C}\right]$ acetate in a non$\left[{ }^{18} \mathrm{~F}\right]$ FDG-avid hepatic metastasis has been described, which showed a reduction in $\left[{ }^{11} \mathrm{C}\right]$ acetate uptake after only 2 weeks of sunitinib treatment [103].

With regard to the high vascularization in RCC lesions, quantification of tumor perfusion using radioactive water $\left(\mathrm{H}_{2}{ }^{15} \mathrm{O}\right)$ may be used to monitor antiangiogenic treatment [91, 104-106]. The injected radioactive water is freely diffusible in tissue [107] and a time-activity curve (TAC) reflecting ${ }^{15} \mathrm{O}$ accumulation in tumors can be generated $[108,109]$. The short half-life of radioactive oxygen ( $\sim 2 \mathrm{~min}$ ) enables serial measurements within a single scan session, but requires the presence of a nearby cyclotron for probe preparation.

Proliferation is an important feature of tumors and can be visualized using 3-deoxy-3-[ $\left.{ }^{18} \mathrm{~F}\right]$ fluorothymidine $\left(\left[{ }^{18} \mathrm{~F}\right]\right.$ FLT) [110]. In patients with recurrent gliomas treated with bevacizumab and irinotecan, $\left[{ }^{18}\right.$ F $]$ FLT PET seemed to be an early marker of OS, which was already predictive at 12 weeks after the start of treatment [111]. Although $\left[{ }^{18} \mathrm{~F}\right]$ FLT uptake was measured in renal transitional cell carcinoma [112], it is currently unknown whether $\left[{ }^{18} \mathrm{~F}\right]$ FLT uptake is a common characteristic of RCC.

Radiolabeled targeted agents

As the PET technique is able to quantify tracer concentrations in absolute units, radiolabeling of targeted agents with shortlived positron-emitting radionuclides, such as carbon- $11\left[{ }^{11} \mathrm{C}\right]$ (half-life: $20.4 \mathrm{~min}$ ) and fluorine-18 $\left[{ }^{18} \mathrm{~F}\right]$ (half-life: $109.8 \mathrm{~min}$ ), is an attractive approach to assess their uptake in tumor lesions. In dynamic PET studies, the optimal kinetic model of an injected tracer can be developed to quantify the tumor uptake of the radiolabeled drug [113]. Currently, several targeted drugs have been radiolabeled as PET tracers and their number is still increasing [114]. These specific PET tracers provide a unique opportunity for personalized treatment planning, since they may be able to predict tumor response before initiation of therapy [114]. Of the targeted agents for treatment of mRCC, $\left[{ }^{89} \mathrm{Zr}\right]$ bevacizumab and $\left[{ }^{18} \mathrm{~F}\right]$ sunitinib have been developed as PET tracers $[115,116]$. PET studies with $\left[{ }^{89} \mathrm{Zr}\right]$ bevacizumab [117] and $\left[{ }^{18} \mathrm{~F}\right]$ sunitinib may not only be used to explore a potential relationship between pre-treatment uptake and response, but might also give insight into drug uptake during treatment and the development of tumor resistance.

\section{Response evaluation of targeted therapy at specific tumor sites}

Primary tumor

Up to $30 \%$ of patients with mRCC present with metastatic disease. In the era of immunotherapy, response of the primary tumor to cytokine-based therapy was very rare [118-120]. Therefore, patients with $\mathrm{mRCC}$ and a resectable primary tumor in situ usually underwent cytoreductive nephrectomy. This treatment strategy was based on the results from two randomized phase III clinical trials demonstrating a longer OS in patients with nephrectomy followed by interferon- $\alpha$ versus patients on interferon- $\alpha$ alone [121-123]. In the era of targeted therapy, however, cytoreductive nephrectomy in patients with asymptomatic primary tumors has become controversial [124], as impressive drug-induced responses have been observed in primary RCC tumors [21]. Moreover, targeted therapy can palliate primary tumor-related symptoms, such as pain and hematuria.

The observed responses in primary RCC lesions have provided opportunities for new treatment approaches in patients who present with synchronous metastases. First, treatment with targeted agents may make cytoreductive nephrectomy unnecessary, preventing patients from perioperative and post-operative complications. A prospective randomized phase III clinical trial is underway addressing the question whether refraining patients from nephrectomy has an impact on their survival. Second, targeted agents can be applied as neoadjuvant therapy to achieve downsizing of the primary tumor that may facilitate cytoreductive nephrectomy [20, 125-127]. A few treatment cycles may be sufficient, as the optimal effect of downsizing primary 
tumors is mostly achieved in the first 3 months [21]. The PD rate in primary tumors, however, varies from $0 \%$ to $47 \%[21,128]$ and mixed responses between the primary tumor and the metastases may occur, indicating that there is a risk of progression of initially resectable primary tumors to inoperability despite a response in metastases [129]. Therefore, appropriate response evaluation is required to early identify mRCC patients with failure of targeted therapy in the primary tumor. Then, when patients develop $\mathrm{PD}$ in resectable primaries in the presence of stable disease in metastases, the treatment plan can be changed rapidly and cytoreductive surgery can be reconsidered.

When using RECIST to determine treatment response in patients with both a primary tumor and metastases, the overall response in these patients may be underestimated. In general, primary tumors of RCC have an enormous size as compared to their metastases $[130,131]$. In addition, large primary tumors show a relatively smaller decrease in size than their metastases during targeted therapy [21, 132]. Consequently, inclusion of large primaries in RECIST measurements can have significant impact on the overall objective response. For that reason, it may be preferable to determine the response in primary tumors and metastases separately and exclude primaries from overall response assessment [133].

Volumetric measurements may give more insight into the response of primary tumors during targeted therapy. We did not find volumetric measurements of sunitinib-treated primary tumors of additional value [21], because one-dimensional changes in size showed a high correlation with volumetric changes. This study indicated that changes in size of the primary tumors can be considered symmetrical and that RECIST measurements are sufficient for evaluation of response to sunitinib. Note that for changes in tumor size, the response criteria are different for one-dimensional (RECIST), two-dimensional (World Health Organization definitions) and three-dimensional (volumetric) measurements, and a PR is reached upon a decrease in tumor size of, respectively, $30 \%, 50 \%$ and $65 \%$ [23].

As targeted therapy in primary tumors is associated with extensive tumor necrosis, assessment of changes in tumor attenuation may be an additional indicator of response. Targeted therapy consisting of sunitinib induced a $31 \%$ reduction in the median volume of the primary tumor and was accompanied by a $39 \%$ increase in the median volume of primary tumor necrosis [21]. In addition, the median decrease in enhancement as measured in one plane of the primary tumor was $13 \%$ in primary tumors treated with sorafenib [126]. With regard to changes in tumor attenuation in primary tumors, the largest series has been described by Cowey et al. [134]. In this retrospective study of $30 \mathrm{mRCC}$ patients treated with sunitinib or sorafenib, a positive relationship between the loss of primary tumor enhancement and the degree of primary tumor shrinkage was seen: a larger percentual decrease in treatment-induced enhancement correlated with a larger percentual decrease in primary tumor size. No relationship was found between the pre-treatment contrast-enhancement and the pre-treatment size of the primary tumor. There were a few patients in whom the change in dimension did not match the degree or direction of change in enhancement, but the clinical significance of this discrepancy is not clear.

\section{Lung metastases}

Lung metastases can be detected in up to $80 \%$ of mRCC patients [135]. Lung lesions can have a rather small size, which may limit specific response measurements. As an example, we have reported that a large number of lung metastases was ineligible for measurement according to the Choi criteria, as these lesions had a size $<15 \mathrm{~mm}$ at baseline [22]. These lesions were still eligible for measurements according to RECIST, as their size was $\geq 10 \mathrm{~mm}$. In addition, assessment of tumor attenuation in lung lesions implies a risk of unreliable mean values due to averaging of attenuation values between soft issue and air.

Targeted therapy is known to cause air-containing cavitations in lung lesions of several solid tumors, including RCC [22] (Fig. 5). Cavitations of lung lesions are especially common in patients with non-small cell lung cancer on treatment with inhibitors of VEGF signaling and platinumbased chemotherapy [136, 137]. Crabb et al. [137] have reported that response evaluation of lung lesions may be improved by incorporation of cavitations into the volume assessment. Incorporation of cavitations into response evaluation of lung metastases of $\mathrm{mRCC}$ is not required as the incidence of cavitations appears to be relatively low [22, 32], likely due to their relatively small size.

\section{Bone metastases}

In RCC, the bone is the second most common site of metastases [135]. In patients without bone metastases, progression of the disease with respect to the bone is easily defined by the development of any new bone lesions during treatment. In case of pre-existent bone metastases, however, response evaluation of targeted therapy is more difficult [138]. Traditionally, all bone lesions were considered as non-target lesions according to RECIST version 1.0 [23]. RECIST version 1.1 states that osteolytic bone lesions with an identifiable soft tissue component, assessed by CT or MRI, can be considered as measurable if the soft tissue component otherwise meets the definition of measurability [23]. Osteoblastic bone lesions, however, are still truly nonmeasurable. Furthermore, PET scan, bone scan, or plain films are not considered adequate imaging techniques to evaluate bone lesions, but these modalities can be used to 
confirm the presence or disappearance of bone lesions [23, 139, 140]. Although several investigators have attempted to validate new criteria for evaluation of bone metastases [140], no consensus has yet been reached.

\section{Brain metastases}

Currently, contrast-enhanced MRI is the best diagnostic test to detect brain metastases [141]. However, in patients with mRCC brain imaging is usually performed when patients present with central nervous system symptoms. Therefore, the experience on evaluation of targeted therapy in brain metastases from mRCC is mostly limited to symptomatic brain metastases. Presently, the reports on the efficacy of targeted therapy in brain metastases of RCC have been conflicting. Brain metastases have been described as the first sign of progression in mRCC patients treated with targeted agents suggesting relatively poor penetrance into the brain [142], whereas responses of brain metastases to targeted therapy have also been described [143-146].

Response evaluation of targeted therapy has been mostly performed in brain metastases that have been pretreated with radiotherapy or surgery. This may make the interpretation of brain imaging during targeted therapy more difficult, as both radiotherapy and surgery cause radiographic changes. After surgery or radiotherapy of the brain, treatment with sorafenib and sunitinib in mRCC patients may cause an increase in peritumoral edema and MRI contrast-enhancement [147]. Such radiographic changes may result from leakage of the drug across the blood brain barrier that is already impaired by previous surgical or radiation intervention [147]. Misinterpretation of these radiographic changes may suggest $\mathrm{PD}$ and the applied treatment as inadequate. In such cases, however, discontinuation of the targeted drug may lead to progressive improvement of edema and MRI enhancement [147].

Brain metastases are associated with vasogenic cerebral edema, which is caused by leakage of fluid from the intravascular space into the brain parenchyma due to the hyperpermeability of the tumor vasculature. This abnormally permeable tumor vasculature is stimulated by VEGF that is secreted by tumor cells. Therefore, targeted agents that block the VEGF signaling pathway may be able to reduce tumor-associated edema by decreasing vascular permeability. In glioblastoma patients, cediranib, a TKI of VEGFR, caused rapid and significant reduction in vasogenic edema which was associated with a decrease in vascular permeability, as measured by the transfer constant $K^{\text {trans }}$ using DCE-MRI [148]. Although DCE-MRI has not yet been evaluated to assess the effects of targeted agents in brain metastases from RCC, similar effects may be expected with agents inhibiting VEGF signaling.

\section{Clinical issues for response evaluation in renal cell cancer}

Functional imaging, such as DCE-US and dynamic PET scans, is increasingly incorporated in the evaluation of the efficacy of anticancer drugs. These imaging techniques usually have a limited field of view, which may be a disadvantage. For example, the field of view of a dynamic PET scan is currently $<20 \mathrm{~cm}$. Therefore, functional imaging can usually not be applied to evaluate the disease in the whole patient. However, the recent trend is towards a reduction of lesions to be measured, as RECIST version 1.1 has reduced the maximum number of target lesions from 10 to 5 [23]. Hillman et al. [149] reported that measurement of $>2$ metastatic lesions did not alter the definitive response in solid tumors. Functional imaging may fail to detect new lesions outside the field of view in case of PD, which is a potential limitation for routine use of these techniques. In addition, functional imaging techniques may be significantly influenced by the hemodynamic changes that are caused by targeted agents, in particular by inhibitors of VEGF signaling. As treatment with these drugs is associated with
Fig. 5 An example of a renal cell cancer patient with lung metastases at baseline (a) and pulmonary cavitations at first response assessment during treatment with sunitinib (b, arrow) [22]
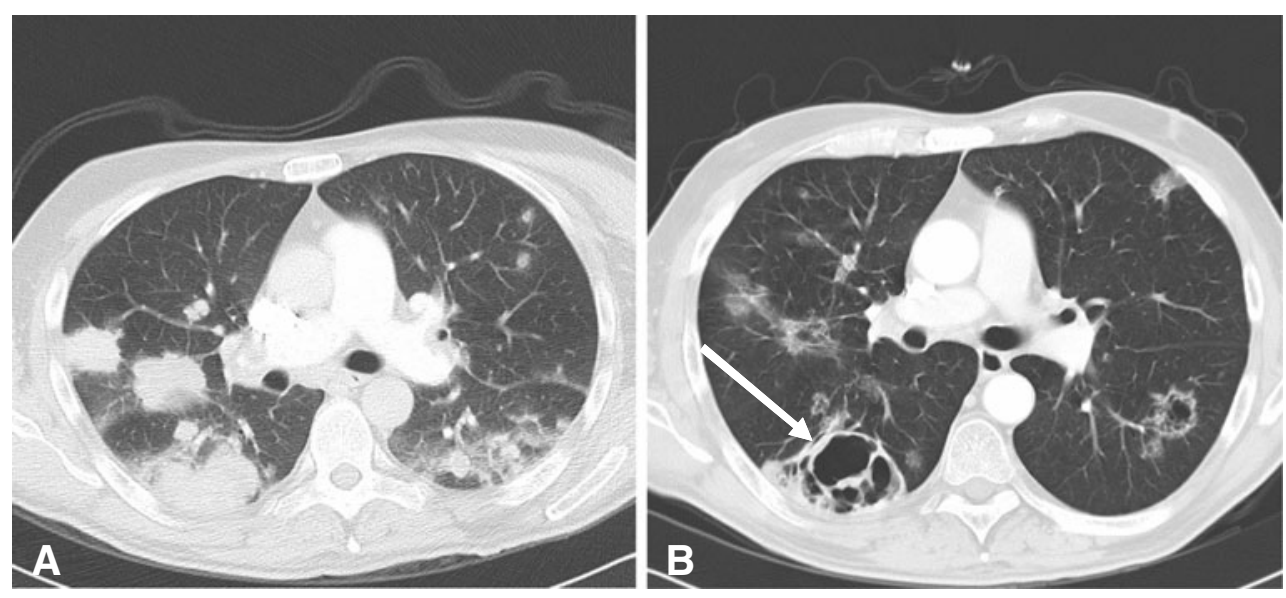
an increase in blood pressure $[150,151]$, a decrease in heart rate [152], and a reduction in capillary density of the normal microcirculation [153], these hemodynamic effects may affect the kinetic parameters that are obtained by functional imaging, such as PET and DCE-MRI. Therefore, methods need to be developed that correct for blood pressure and cardiac output in the kinetic modeling of functional imaging techniques.

Before implementation of new imaging tools and changes in response evaluation criteria to determine the efficacy of targeted therapies in the clinic, the feasibility, accuracy and reproducibility of the new method should be determined. For the assessment of tumor response, the test-retest reproducibility of the method needs to be known in order to determine the minimal change in the variable that represents a true treatment effect. In particular, when relatively small changes are already considered as tumor response, the test-retest reproducibility needs to be high. In addition, there is a need for standardized protocols including timing of response evaluation, acquisition of imaging data and data analysis in order to optimally compare the results in individual patients at different time-points, but also to enable exchange of data among different institutions. With regard to the timing of response assessment, specific attention should be paid to sunitinib, as this TKI is usually administered in a schedule consisting of 4 weeks on treatment followed by a 2 -week rest period [154]. Since temporary discontinuation of sunitinib may result in flare-up mimicking PD [155], response measurements should not be performed during the rest period.

\section{Conclusions}

As targeted therapy causes disease stabilization rather than substantial tumor regression, new response criteria and imaging techniques have recently been developed for evaluation of the efficacy of these molecules in mRCC patients. RECIST is usually applied to assess tumor response in $\mathrm{mRCC}$ and is able to identify patients with clinical benefit. However, RECIST is not able to early identify mRCC patients with a poor PFS during targeted therapy. Incorporation of treatmentinduced changes in tumor attenuation on contrast-enhanced CT may have additional value to assess tumor response, but it is not clear whether inclusion of these changes in decisionmaking has significant impact on the current management of $\mathrm{mRCC}$ patients. Functional imaging techniques including DCE-CT, DCE-MRI, DCE-US and PET are under investigation for response evaluation in $\mathrm{mRCC}$. The first reports are promising, but further studies are required to validate the usefulness of these imaging techniques in $\mathrm{mRCC}$ patients early during targeted therapy.
Acknowledgements We thank N. Lassau for permission to reproduce Figs. 3 and 4.

Conflict of interest statement No funds were received in support of this study.

Open Access This article is distributed under the terms of the Creative Commons Attribution Noncommercial License which permits any noncommercial use, distribution, and reproduction in any medium, provided the original author(s) and source are credited.

\section{References}

1. Parkin DM, Bray F, Ferlay J, Pisani P (2005) Global cancer statistics, 2002. CA Cancer J Clin 55:74-108

2. Pantuck AJ, Zisman A, Belldegrun AS (2001) The changing natural history of renal cell carcinoma. J Urol 166:1611-1623

3. Motzer RJ, Bukowski RM (2006) Targeted therapy for metastatic renal cell carcinoma. J Clin Oncol 24:5601-5608

4. Brugarolas J (2007) Renal-cell carcinoma-molecular pathways and therapies. N Engl J Med 356:185-187

5. Kerbel RS (2008) Tumor Angiogenesis. N Engl J Med 358:2039-2049

6. Escudier B, Bellmunt J, Negrier S, Bajetta E, Melichar B, Bracarda S, Ravaud A, Golding S, Jethwa S, Sneller V (2010) Phase III trial of bevacizumab plus interferon alfa-2a in patients with metastatic renal cell carcinoma (AVOREN): final analysis of overall survival. J Clin Oncol 28:2144-2150

7. Escudier B, Eisen T, Stadler WM, Szczylik C, Oudard S, Siebels M, Negrier S, Chevreau C, Solska E, Desai AA, Rolland F, Demkow T, Hutson TE, Gore M, Freeman S, Schwartz B, Shan M, Simantov R, Bukowski RM (2007) Sorafenib in advanced clear-cell renal-cell carcinoma. N Engl J Med 356:125-134

8. Motzer RJ, Hutson TE, Tomczak P, Michaelson MD, Bukowski RM, Rixe O, Oudard S, Negrier S, Szczylik C, Kim ST, Chen I, Bycott PW, Baum CM, Figlin RA (2007) Sunitinib versus interferon alfa in metastatic renal-cell carcinoma. N Engl J Med 356:115-124

9. Rini BI, Wilding G, Hudes G, Stadler WM, Kim S, Tarazi J, Rosbrook B, Trask PC, Wood L, Dutcher JP (2009) Phase II study of axitinib in sorafenib-refractory metastatic renal cell carcinoma. J Clin Oncol 27:4462-4468

10. Rixe O, Bukowski RM, Michaelson MD, Wilding G, Hudes GR, Bolte O, Motzer RJ, Bycott P, Liau KF, Freddo J, Trask PC, Kim S, Rini BI (2007) Axitinib treatment in patients with cytokinerefractory metastatic renal-cell cancer: a phase II study. Lancet Oncol 8:975-984

11. Sternberg CN, Davis ID, Mardiak J, Szczylik C, Lee E, Wagstaff J, Barrios CH, Salman P, Gladkov OA, Kavina A, Zarba JJ, Chen M, McCann L, Pandite L, Roychowdhury DF, Hawkins RE (2010) Pazopanib in locally advanced or metastatic renal cell carcinoma: results of a randomized phase III trial. J Clin Oncol 28:1061-1068

12. Escudier B, Pluzanska A, Koralewski P, Ravaud A, Bracarda S, Szczylik C, Chevreau C, Filipek M, Melichar B, Bajetta E, Gorbunova V, Bay JO, Bodrogi I, Jagiello-Gruszfeld A, Moore N (2007) Bevacizumab plus interferon alfa-2a for treatment of metastatic renal cell carcinoma: a randomised, double-blind phase III trial. Lancet 370:2103-2111

13. Motzer RJ, Hutson TE, Tomczak P, Michaelson MD, Bukowski RM, Oudard S, Negrier S, Szczylik C, Pili R, Bjarnason GA, Garcia-del-Muro X, Sosman JA, Solska E, Wilding G, Thompson JA, Kim ST, Chen I, Huang X, Figlin RA (2009) Overall 
survival and updated results for sunitinib compared with interferon alfa in patients with metastatic renal cell carcinoma. J Clin Oncol 27:3584-3590

14. Brugarolas JB, Vazquez F, Reddy A, Sellers WR, Kaelin J (2003) TSC2 regulates VEGF through mTOR-dependent and independent pathways. Cancer Cell 4:147-158

15. Hudson CC, Liu M, Chiang GG, Otterness DM, Loomis DC, Kaper F, Giaccia AJ, Abraham RT (2002) Regulation of hypoxia-inducible factor 1 \{alpha\} expression and function by the mammalian target of rapamycin. Mol Cell Biol 22:7004-7014

16. Majumder PK, Febbo PG, Bikoff R, Berger R, Xue Q, McMahon LM, Manola J, Brugarolas J, McDonnell TJ, Golub TR, Loda M, Lane HA, Sellers WR (2004) mTOR inhibition reverses Aktdependent prostate intraepithelial neoplasia through regulation of apoptotic and HIF-1-dependent pathways. Nat Med 10:594-601

17. Hudes G, Carducci M, Tomczak P, Dutcher J, Figlin R, Kapoor A, Staroslawska E, Sosman J, McDermott D, Bodrogi I, Kovacevic Z, Lesovoy V, Schmidt-Wolf IGH, Barbarash O, Gokmen E, O'Toole T, Lustgarten S, Moore L, Motzer RJ, the Global ARCC (2007) Temsirolimus, interferon alfa, or both for advanced renal-cell carcinoma. N Engl J Med 356:2271-2281

18. Motzer RJ, Escudier B, Oudard S, Hutson TE, Porta C, Bracarda S, Grünwald V, Thompson JA, Figlin RA, Hollaender N, Urbanowitz G, Berg WJ, Kay A, Lebwohl D, Ravaud A (2008) Efficacy of everolimus in advanced renal cell carcinoma: a double-blind, randomised, placebo-controlled phase III trial. Lancet 372:449-456

19. Horger M, Lauer U, Schraml C, Berg C, Koppenhofer U, Claussen C, Gregor M, Bitzer M (2009) Early MRI response monitoring of patients with advanced hepatocellular carcinoma under treatment with the multikinase inhibitor sorafenib. BMC Cancer 9:208

20. Rodriguez Faba O, Breda A, Rosales A, Palou J, Algaba F, Maroto Rey P, Villavicencio H (2010) Neoadjuvant temsirolimus effectiveness in downstaging advanced non-clear cell renal cell carcinoma. Eur Urol: in press

21. Van der Veldt AA, Meijerink MR, Van den Eertwegh AJ, Bex A, De Gast G, Haanen JB, Boven E (2008) Sunitinib for treatment of advanced renal cell cancer: primary tumor response. Clin Cancer Res 14:2431-2436

22. Van der Veldt AA, Meijerink MR, Van den Eertwegh AJ, Haanen JB, Boven E (2010) Choi response criteria for early prediction of clinical outcome in patients with metastatic renal cell cancer treated with sunitinib. Br J Cancer 102:803-809

23. Eisenhauer EA, Therasse P, Bogaerts J, Schwartz LH, Sargent D, Ford R, Dancey J, Arbuck S, Gwyther S, Mooney M, Rubinstein L, Shankar L, Dodd L, Kaplan R, Lacombe D, Verweij J (2009) New response evaluation criteria in solid tumours: revised RECIST guideline (version 1.1). Eur J Cancer 45:228-247

24. Van Cruijsen H, Van der Veldt AA, Hoekman K (2009) Tyrosine kinase inhibitors of VEGF receptors: clinical issues and remaining questions. Front Biosci 14:2248-2268

25. Therasse P, Arbuck SG, Eisenhauer EA, Wanders J, Kaplan RS, Rubinstein L, Verweij J, Van Glabbeke M, Van Oosterom AT, Christian MC, Gwyther SG (2000) New guidelines to evaluate the response to treatment in solid tumors. J Natl Cancer Inst 92:205-216

26. Thiam R, Fournier LS, Trinquart L, Medioni J, Chatellier G, Balvay D, Escudier B, Dromain C, Cuenod CA, Oudard S (2010) Optimizing the size variation threshold for the CT evaluation of response in metastatic renal cell carcinoma treated with sunitinib. Ann Oncol 21:936-941

27. Jinzaki M, Tanimoto A, Mukai M, Ikeda E, Kobayashi S, Yuasa Y, Narimatsu Y, Murai M (2000) Double-phase helical CT of small renal parenchymal neoplasms: correlation with pathologic findings and tumor angiogenesis. J Comput Assist Tomogr 24:835-842
28. Miles KA (1999) Tumour angiogenesis and its relation to contrast enhancement on computed tomography: a review. Eur J Radiol 30:198-205

29. Miles KA, Charnsangavej C, Lee FT, Fishman EK, Horton K, Lee TY (2000) Application of CT in the investigation of angiogenesis in oncology. Acad Radiol 7:840-850

30. Han KS, Jung DC, Choi HJ, Jeong MS, Cho KS, Joung JY, Seo HK, Lee KH, Chung J (2010) Pretreatment assessment of tumor enhancement on contrast-enhanced computed tomography as a potential predictor of treatment outcome in metastatic renal cell carcinoma patients receiving antiangiogenic therapy. Cancer 116:2332-2342

31. Baccala A Jr, Hedgepeth R, Kaouk J, Magi-Galluzzi C, Gilligan T, Fergany A (2007) Pathological evidence of necrosis in recurrent renal mass following treatment with sunitinib. Int $\mathrm{J}$ Urol 14:1095-1097

32. Smith AD, Lieber ML, Shah SN (2010) Assessing tumor response and detecting recurrence in metastatic renal cell carcinoma on targeted therapy: importance of size and attenuation on contrast-enhanced CT. Am J Roentgenol 194:157-165

33. Benjamin RS, Choi H, Macapinlac HA, Burgess MA, Patel SR, Chen LL, Podoloff DA, Charnsangavej C (2007) We should desist using RECIST, at least in GIST. J Clin Oncol 25:1760-1764

34. Choi H, Charnsangavej C, Faria SC, Macapinlac HA, Burgess MA, Patel SR, Chen LL, Podoloff DA, Benjamin RS (2007) Correlation of computed tomography and positron emission tomography in patients with metastatic gastrointestinal stromal tumor treated at a single institution with imatinib mesylate: proposal of new computed tomography response criteria. J Clin Oncol 25:1753-1759

35. Maksimovic O, Schraml C, Hartmann JT, Bitzer M, Claussen CD, Pintoffl J, Horger M (2010) Evaluation of response in malignant tumors treated with the multitargeted tyrosine kinase inhibitor sorafenib: a multitechnique imaging assessment. Am J Roentgenol 194:5-14

36. Nathan PD, Vinayan A, Stott D, Juttla J, Goh V (2010) CT response assessment combining reduction in both size and arterial phase density correlates with time to progression in metastatic renal cancer patients treated with targeted therapies. Cancer Biol Ther 9:15-19

37. Chu TF, Rupnick MA, Kerkela R, Dallabrida SM, Zurakowski D, Nguyen L, Woulfe K, Pravda E, Cassiola F, Desai J, George S, Morgan JA, Harris DM, Ismail NS, Chen JH, Schoen FJ, Van den Abbeele AD, Demetri GD, Force T, Chen MH (2007) Cardiotoxicity associated with tyrosine kinase inhibitor sunitinib. Lancet 370:2011-2019

38. Koukourakis MI, Mavanis I, Kouklakis G, Pitiakoudis M, Minopoulos G, Manolas C, Simopoulos C (2007) Early antivascular effects of bevacizumab anti-VEGF monoclonal antibody on colorectal carcinomas assessed with functional CT imaging. Am J Clin Oncol 30:315-318

39. Meijerink MR, Van Cruijsen H, Hoekman K, Kater M, Van Schaik C, Van Waesberghe JH, Giaccone G, Manoliu RA (2007) The use of perfusion CT for the evaluation of therapy combining AZD2171 with gefitinib in cancer patients. Eur Radiol 17:1700-1713

40. Sahani DV, Kalva SP, Hamberg LM, Hahn PF, Willett CG, Saini S, Mueller PR, Lee TY (2005) Assessing tumor perfusion and treatment response in rectal cancer with multisection CT: initial observations. Radiology 234:785-792

41. Zhu AX, Holalkere NS, Muzikansky A, Horgan K, Sahani DV (2008) Early antiangiogenic activity of bevacizumab evaluated by computed tomography perfusion scan in patients with advanced hepatocellular carcinoma. Oncologist 13:120-125

42. Wang JH, Min PQ, Wang PJ, Cheng WX, Zhang XH, Wang Y, Zhao XH, Mao XQ (2006) Dynamic CT evaluation of tumor 
vascularity in renal cell carcinoma. AJR Am J Roentgenol 186:1423-1430

43. Hylton N (2006) Dynamic contrast-enhanced magnetic resonance imaging as an imaging biomarker. J Clin Oncol 24:3293-3298

44. O'Connor JP, Jackson A, Parker GJ, Jayson GC (2007) DCEMRI biomarkers in the clinical evaluation of antiangiogenic and vascular disrupting agents. Br J Cancer 96:189-195

45. Jackson A, O'Connor JPB, Parker GJM, Jayson GC (2007) Imaging tumor vascular heterogeneity and angiogenesis using dynamic contrast-enhanced magnetic resonance imaging. Clin Cancer Res 13:3449-3459

46. Galbraith SM, Maxwell RJ, Lodge MA, Tozer GM, Wilson J, Taylor NJ, Stirling JJ, Sena L, Padhani AR, Rustin GJS (2003) Combretastatin A4 phosphate has tumor antivascular activity in rat and man as demonstrated by dynamic magnetic resonance imaging. J Clin Oncol 21:2831-2842

47. Liu G, Rugo HS, Wilding G, McShane TM, Evelhoch JL, Ng C, Jackson E, Kelcz F, Yeh BM, Lee FT Jr, Charnsangavej C, Park JW, Ashton EA, Steinfeldt HM, Pithavala YK, Reich SD, Herbst RS (2005) Dynamic contrast-enhanced magnetic resonance imaging as a pharmacodynamic measure of response after acute dosing of AG-013736, an oral angiogenesis inhibitor, in patients with advanced solid tumors: results from a phase I study. J Clin Oncol 23:5464-5473

48. Morgan B, Thomas AL, Drevs J, Hennig J, Buchert M, Jivan A, Horsfield MA, Mross K, Ball HA, Lee L, Mietlowski W, Fuxius S, Unger C, O'Byrne K, Henry A, Cherryman GR, Laurent D, Dugan M, Marme D, Steward WP (2003) Dynamic contrastenhanced magnetic resonance imaging as a biomarker for the pharmacological response of PTK787/ZK 222584, an inhibitor of the vascular endothelial growth factor receptor tyrosine kinases, in patients with advanced colorectal cancer and liver metastases: results from two phase I studies. J Clin Oncol 21:3955-3964

49. Flaherty KT, Rosen MA, Heitjan DF, Gallagher ML, Schwartz B, Schnall MD, O'Dwyer PJ (2008) Pilot study of DCE-MRI to predict progression-free survival with sorafenib therapy in renal cell carcinoma. Cancer Biol Ther 7:496-501

50. Hahn OM, Yang C, Medved M, Karczmar G, Kistner E, Karrison T, Manchen E, Mitchell M, Ratain MJ, Stadler WM (2008) Dynamic contrast-enhanced magnetic resonance imaging pharmacodynamic biomarker study of sorafenib in metastatic renal carcinoma. J Clin Oncol 26:4572-4578

51. Hillman GG, Singh-Gupta V, Zhang H, Al Bashir AK, Katkuri Y, Li M, Yunker CK, Patel AD, Abrams J, Haacke EM (2009) Dynamic contrast-enhanced magnetic resonance imaging of vascular changes induced by sunitinib in papillary renal cell carcinoma xenograft tumors. Neoplasia 11:910-920

52. Rosen MA, Schnall MD (2007) Dynamic contrast-enhanced magnetic resonance imaging for assessing tumor vascularity and vascular effects of targeted therapies in renal cell carcinoma. Clin Cancer Res 13:770s-776s

53. De Bazelaire C, Rofsky NM, Duhamel G, Michaelson MD, George D, Alsop DC (2005) Arterial spin labeling blood flow magnetic resonance imaging for the characterization of metastatic renal cell carcinoma1. Acad Radiol 12:347-357

54. Schor-Bardach R, Alsop DC, Pedrosa I, Solazzo SA, Wang X, Marquis RP, Atkins MB, Regan M, Signoretti S, Lenkinski RE, Goldberg SN (2009) Does arterial spin-labeling MR imagingmeasured tumor perfusion correlate with renal cell cancer response to antiangiogenic therapy in a mouse model? Radiology 251:731-742

55. De Bazelaire C, Alsop DC, George D, Pedrosa I, Wang Y, Michaelson MD, Rofsky NM (2008) Magnetic resonance imaging-measured blood flow change after antiangiogenic therapy with PTK787/ZK 222584 correlates with clinical outcome in metastatic renal cell carcinoma. Clin Cancer Res 14:5548-5554

56. Boss A, Martirosian P, Schraml C, Clasen S, Fenchel M, Anastasiadis A, Claussen CD, Pereira PL, Schick F (2006) Morphological, contrast-enhanced and spin labeling perfusion imaging for monitoring of relapse after RF ablation of renal cell carcinomas. Eur Radiol 16:1226-1236

57. Taouli B, Thakur RK, Mannelli L, Babb JS, Kim S, Hecht EM, Lee VS, Israel GM (2009) Renal lesions: characterization with diffusion-weighted imaging versus contrast-enhanced MR imaging. Radiology 251:398-407

58. Harry VN, Semple SI, Parkin DE, Gilbert FJ (2010) Use of new imaging techniques to predict tumour response to therapy. Lancet Oncol 11:92-102

59. Mardor Y, Pfeffer R, Spiegelmann R, Roth Y, Maier SE, Nissim O, Berger R, Glicksman A, Baram J, Orenstein A, Cohen JS, Tichler T (2003) Early detection of response to radiation therapy in patients with brain malignancies using conventional and high $\mathrm{b}$-value diffusion-weighted magnetic resonance imaging. J Clin Oncol 21:1094-1100

60. Moffat BA, Chenevert TL, Lawrence TS, Meyer CR, Johnson TD, Dong Q, Tsien C, Mukherji S, Quint DJ, Gebarski SS, Robertson PL, Junck LR, Rehemtulla A, Ross BD (2005) Functional diffusion map: a noninvasive MRI biomarker for early stratification of clinical brain tumor response. Proc Nat Acad Sci USA 102:5524-5529

61. Dzik-Jurasz A, Domenig C, George M, Wolber J, Padhani A, Brown G, Doran S (2002) Diffusion MRI for prediction of response of rectal cancer to chemoradiation. Lancet 360:307-308

62. Lee KC, Bradley DA, Hussain M, Meyer CR, Chenevert TL, Jacobson JA, Johnson TD, Galban CJ, Rehemtulla A, Pienta KJ, Ross BD (2007) A feasibility study evaluating the functional diffusion map as a predictive imaging biomarker for detection of treatment response in a patient with metastatic prostate cancer to the bone. Neoplasia 9:1003-1011

63. Kamel IR, Bluemke DA, Eng J, Liapi E, Messersmith W, Reyes DK, Geschwind JF (2006) The role of functional MR imaging in the assessment of tumor response after chemoembolization in patients with hepatocellular carcinoma. J Vasc Interv Radiol 17:505-512

64. Paudyal B, Paudyal P, Tsushima Y, Oriuchi N, Amanuma M, Miyazaki M, Taketomi-Takahashi A, Nakazato Y, Endo K (2010) The role of the ADC value in the characterisation of renal carcinoma by diffusion-weighted MRI. Br J Radiol 83:336-343

65. Pedrosa I, Alsop DC, Rofsky NM (2009) Magnetic resonance imaging as a biomarker in renal cell carcinoma. Cancer 115:2334-2345

66. Sandrasegaran K, Sundaram CP, Ramaswamy R, Akisik FM, Rydberg MP, Lin C, Aisen AM (2010) Usefulness of diffusionweighted imaging in the evaluation of renal masses. AJR Am J Roentgenol 194:438-445

67. Squillaci E, Manenti G, Cova M, Di RM, Miano R, Palmieri G, Simonetti G (2004) Correlation of diffusion-weighted MR imaging with cellularity of renal tumours. Anticancer Res 24:4175-4179

68. Squillaci E, Manenti G, Di SF, Miano R, Strigari L, Simonetti G (2004) Diffusion-weighted MR imaging in the evaluation of renal tumours. J Exp Clin Cancer Res 23:39-45

69. Byun WM, Shin SO, Chang Y, Lee SJ, Finsterbusch J, Frahm J (2002) Diffusion-weighted MR imaging of metastatic disease of the spine: assessment of response to therapy. AJNR Am J Neuroradiol 23:906-912

70. Lassau N, Chami L, Benatsou B, Peronneau P, Roche A (2007) Dynamic contrast-enhanced ultrasonography (DCE-US) with quantification of tumor perfusion: a new diagnostic tool to evaluate the early effects of antiangiogenic treatment. Eur Radiol 17(Suppl 6):F89-F98 
71. Kabakci N, Igci E, Secil M, Yorukoglu K, Mungan U, Celebi I, Kirkali Z (2005) Echo contrast-enhanced power doppler ultrasonography for assessment of angiogenesis in renal cell carcinoma. J Ultrasound Med 24:747-753

72. Lassau N, Chebil M, Chami L, Bidault S, Girard E, Roche A (2010) Dynamic contrast-enhanced ultrasonography (DCE-US): a new tool for the early evaluation of antiangiogenic treatment. Target Oncol 5:53-38

73. Lassau N, Koscielny S, Opolon P, De Baere T, Peronneau P, Leclere J, Roche A (2001) Evaluation of contrast-enhanced color doppler ultrasound for the quantification of angiogenesis in vivo. Invest Radiol 36:50-55

74. Krix M, Kiessling F, Farhan N, Schmidt K, Hoffend J, Delorme S (2003) A multivessel model describing replenishment kinetics of ultrasound contrast agent for quantification of tissue perfusion. Ultrasound Med Biol 29:1421-1430

75. Lamuraglia M, Escudier B, Chami L, Schwartz B, Leclere J, Roche A, Lassau N (2006) To predict progression-free survival and overall survival in metastatic renal cancer treated with sorafenib: pilot study using dynamic contrast-enhanced Doppler ultrasound. Eur J Cancer 42:2472-2479

76. Lassau N, Koscielny S, Albiges L, Chami L, Benatsou B, Chebil M, Roche A, Escudier BJ (2010) Metastatic renal cell carcinoma treated with sunitinib: early evaluation of treatment response using dynamic contrast-enhanced ultrasonography. Clin Cancer Res 16:1216-1225

77. Lassau N, Lamuraglia M, Chami L, Leclere J, Bonvalot S, Terrier P, Roche A, Le Cesne A (2006) Gastrointestinal stromal tumors treated with imatinib: monitoring response with contrastenhanced sonography. Am J Roentgenol 187:1267-1273

78. Escudier B, Lassau N, Angevin E, Soria JC, Chami L, Lamuraglia M, Zafarana E, Landreau V, Schwartz B, Brendel E, Armand JP, Robert C (2007) Phase I trial of sorafenib in combination with IFN alpha-2a in patients with unresectable and/or metastatic renal cell carcinoma or malignant melanoma. Clin Cancer Res 13:1801-1809

79. Battistella M, Mateus C, Lassau N, Chami L, Boukoucha M, Duvillard P, Cribier B, Robert C (2010) Sunitinib efficacy in the treatment of metastatic skin adnexal carcinomas: report of two patients with hidradenocarcinoma and trichoblastic carcinoma. J Eur Acad Dermatol Venereol 24:199-203

80. Rouffiac V, Bouquet C, Lassau N, Opolon P, Koscielny S, Peronneau P, Perricaudet M, Roche A (2004) Validation of a new method for quantifying in vivo murine tumor necrosis by sonography. Invest Radiol 39:350-356

81. Gambhir SS (2002) Molecular imaging of cancer with positron emission tomography. Nat Rev Cancer 2:683-693

82. Nakatani K, Nakamoto Y, Saga T, Higashi T, Togashi K (2010) The potential clinical value of FDG-PET for recurrent renal cell carcinoma. Eur J Radiol: in press

83. Aide N, Cappele O, Bottet P, Bensadoun H, Regeasse A, Comoz F, Sobrio F, Bouvard G, Agostini D (2003) Efficiency of [(18)F] FDG PET in characterising renal cancer and detecting distant metastases: a comparison with CT. Eur J Nucl Med Mol Imaging 30:1236-1245

84. Majhail NS, Urbain JL, Albani JM, Kanvinde MH, Rice TW, Novick AC, Mekhail TM, Olencki TE, Elson P, Bukowski RM (2003) F-18 fluorodeoxyglucose positron emission tomography in the evaluation of distant metastases from renal cell carcinoma. J Clin Oncol 21:3995-4000

85. Park JW, Jo MK, Lee HM (2009) Significance of 18Ffluorodeoxyglucose positron-emission tomography/computed tomography for the postoperative surveillance of advanced renal cell carcinoma. BJU Int 103:615-619

86. Miyakita H, Tokunaga M, Onda H, Usui Y, Kinoshita H, Kawamura N, Yasuda S (2002) Significance of 18F- fluorodeoxyglucose positron emission tomography (FDG-PET) for detection of renal cell carcinoma and immunohistochemical glucose transporter 1 (GLUT-1) expression in the cancer. Int $\mathrm{J}$ Urol 9:15-18

87. Ramdave S, Thomas GW, Berlangieri SU, Bolton DM, Davis I, Danguy HT, Macgregor D, Scott AM (2001) Clinical role of F-18 fluorodeoxyglucose positron emission tomography for detection and management of renal cell carcinoma. J Urol 166:825-830

88. Brouwers AH, Dorr U, Lang O, Boerman OC, Oyen WJ, Steffens MG, Oosterwijk E, Mergenthaler HG, Bihl H, Corstens FH (2002) 131 I-cG250 monoclonal antibody immunoscintigraphy versus $[18 \mathrm{~F}]$ FDG-PET imaging in patients with metastatic renal cell carcinoma: a comparative study. Nucl Med Commun 23:229-236

89. Beyer T, Townsend DW, Brun T, Kinahan PE, Charron M, Roddy R, Jerin J, Young J, Byars L, Nutt R (2000) A combined PET/CT scanner for clinical oncology. J Nucl Med 41:13691379

90. Jennens RR, Rosenthal MA, Lindeman GJ, Michael M (2004) Complete radiological and metabolic response of metastatic renal cell carcinoma to SU5416 (semaxanib) in a patient with probable von Hippel-Lindau syndrome. Urol Oncol 22:193-196

91. Lara PN Jr, Quinn DI, Margolin K, Meyers FJ, Longmate J, Frankel P, Mack PC, Turrell C, Valk P, Rao J, Buckley P, Wun T, Gosselin R, Galvin I, Gumerlock PH, Lenz HJ, Doroshow JH, Gandara DR (2003) SU5416 plus interferon alpha in advanced renal cell carcinoma: a phase II California Cancer Consortium Study with biological and imaging correlates of angiogenesis inhibition. Clin Cancer Res 9:4772-4781

92. Lyrdal D, Boijsen M, Suurkula M, Lundstam S, Stierner U (2009) Evaluation of sorafenib treatment in metastatic renal cell carcinoma with 2-fluoro-2-deoxyglucose positron emission tomography and computed tomography. Nucl Med Commun 30:519-524

93. Vercellino L, Bousquet G, Baillet G, Barre E, Mathieu O, Just PA, Desgrandchamps F, Misset JL, Hindie E, Moretti JL (2009) 18F-FDG PET/CT imaging for an early assessment of response to sunitinib in metastatic renal carcinoma: preliminary study. Cancer Biother Radiopharm 24:137-144

94. Van Oosterom AT, Judson I, Verweij J, Stroobants S, Di Paola ED, Dimitrijevic S, Martens M, Webb A, Sciot R, Van Glabbeke M, Silberman S, Nielsen OS (2001) Safety and efficacy of imatinib (STI571) in metastatic gastrointestinal stromal tumours: a phase I study. Lancet 358:1421-1423

95. Stroobants S, Goeminne J, Seegers M, Dimitrijevic S, Dupont $P$, Nuyts J, Martens M, Van den Borne B, Cole P, Sciot R, Dumez H, Silberman S, Mortelmans L, Van Oosterom A (2003) 18FDGPositron emission tomography for the early prediction of response in advanced soft tissue sarcoma treated with imatinib mesylate (Glivec). Eur J Cancer 39:2012-2020

96. Nogova L, Boellaard R, Kobe C, Hoetjes N, Zander T, Gross SH, Dimitrijevic S, Pellas T, Eschner W, Schmidt K, Bangard C, Hayes W, Thomas RK, Dietlein M, Giaccone G, Hoekstra OS, Lammertsma AA, Wolf J (2009) Downregulation of 18F-FDG uptake in PET as an early pharmacodynamic effect in treatment of non-small cell lung cancer with the mTOR inhibitor everolimus. J Nucl Med 50:1815-1819

97. Prior JO, Montemurro M, Orcurto MV, Michielin O, Luthi F, Benhattar J, Guillou L, Elsig V, Stupp R, Delaloye AB, Leyvraz S (2009) Early prediction of response to sunitinib after imatinib failure by $18 \mathrm{~F}$-fluorodeoxyglucose positron emission tomography in patients with gastrointestinal stromal tumor. J Clin Oncol 27:439-445

98. Wahl RL, Jacene H, Kasamon Y, Lodge MA (2009) From RECIST to PERCIST: evolving considerations for PET response criteria in solid tumors. J Nucl Med 50:122S-150S 
99. Boellaard R, O'Doherty MJ, Weber WA, Mottaghy FM, Lonsdale MN, Stroobants SG, Oyen WJ, Kotzerke J, Hoekstra OS, Pruim J, Marsden PK, Tatsch K, Hoekstra CJ, Visser EP, Arends B, Verzijlbergen FJ, Zijlstra JM, Comans EF, Lammertsma AA, Paans AM, Willemsen AT, Beyer T, Bockisch A, Schaefer-Prokop C, Delbeke D, Baum RP, Chiti A, Krause BJ (2010) FDG PET and PET/CT: EANM procedure guidelines for tumour PET imaging: version 1.0. Eur J Nucl Med Mol Imaging 37:181-200

100. Shreve P, Chiao PC, Humes HD, Schwaiger M, Gross MD (1995) Carbon-11-Acetate PET imaging in renal disease. J Nucl Med 36:1595-1601

101. Shreve PD, Gross MD (1997) Imaging of the pancreas and related diseases with PET carbon-11-acetate. J Nucl Med 38:1305-1310

102. Oyama N, Akino H, Kanamaru H, Suzuki Y, Muramoto S, Yonekura Y, Sadato N, Yamamoto K, Okada K (2002) 11CAcetate PET imaging of prostate cancer. J Nucl Med 43:181-186

103. Maleddu A, Pantaleo MA, Castellucci P, Astorino M, Nanni C, Nannini M, Busato F, Di BM, Farsad M, Lodi F, Boschi S, Fanti S, Biasco G (2009) 11C-acetate PET for early prediction of sunitinib response in metastatic renal cell carcinoma. Tumori 95:382-384

104. Anderson H, Yap JT, Wells P, Miller MP, Propper D, Price P, Harris AL (2003) Measurement of renal tumour and normal tissue perfusion using positron emission tomography in a phase II clinical trial of razoxane. Br J Cancer 89:262-267

105. Anderson HL, Yap JT, Miller MP, Robbins A, Jones T, Price PM (2003) Assessment of pharmacodynamic vascular response in a phase I trial of combretastatin A4 phosphate. J Clin Oncol 21:2823-2830

106. Herbst RS, Mullani NA, Davis DW, Hess KR, McConkey DJ, Charnsangavej C, O'Reilly MS, Kim HW, Baker C, Roach J, Ellis LM, Rashid A, Pluda J, Bucana C, Madden TL, Tran HT, Abbruzzese JL (2002) Development of biologic markers of response and assessment of antiangiogenic activity in a clinical trial of human recombinant endostatin. J Clin Oncol 20:3804-3814

107. De Langen AJ, Van den Boogaart V, Marcus JT, Lubberink M (2008) Use of H2(15)O-PET and DCE-MRI to measure tumor blood flow. Oncologist 13:631-644

108. Lubberink M, Van der Veldt A, Knaapen P, Harms H, Smit E, Hendrikse H, Lammertsma A (2009) Measurement of tumor and myocardial perfusion using 15O-water and a clinical PET-CT scanner. J Nucl Med Meeting 50(Supplement 2):238

109. Hoekstra CJ, Stroobants SG, Hoekstra OS, Smit EF, Vansteenkiste JF, Lammertsma AA (2002) Measurement of perfusion in stage IIIA-N2 non-small cell lung cancer using $\mathrm{H} 215 \mathrm{O}$ and positron emission tomography. Clin Cancer Res 8:2109-2115

110. Shields AF, Grierson JR, Dohmen BM, Machulla HJ, Stayanoff JC, Lawhorn-Crews JM, Obradovich JE, Muzik O, Mangner TJ (1998) Imaging proliferation in vivo with [F-18]FLT and positron emission tomography. Nat Med 4:1334-1336

111. Chen W, Delaloye S, Silverman DHS, Geist C, Czernin J, Sayre J, Satyamurthy N, Pope W, Lai A, Phelps ME, Cloughesy T (2007) Predicting treatment response of malignant gliomas to bevacizumab and irinotecan by imaging proliferation with [18F] fluorothymidine positron emission tomography: a pilot study. J Clin Oncol 25:4714-4721

112. Lawrentschuk NM, Poon AMTM, Scott AMM (2006) Fluorine18 Fluorothymidine: a new positron emission radioisotope for renal tumors. Clin Nucl Med 31:788-789

113. Rosso L, Brock CS, Gallo JM, Saleem A, Price PM, Turkheimer FE, Aboagye EO (2009) A new model for prediction of drug distribution in tumor and normal tissues: pharmacokinetics of temozolomide in glioma patients. Cancer Res 69:120-127

114. Van der Veldt AA, Luurtsema G, Lubberink M, Lammertsma AA, Hendrikse NH (2008) Individualized treatment planning in oncology: role of PET and radiolabelled anticancer drugs in predicting tumour resistance. Curr Pharm Des 14:2914-2931
115. Nagengast WB, De Vries EG, Hospers GA, Mulder NH, De Jong JR, Hollema H, Brouwers AH, Van Dongen GA, Perk LR, Lubde Hooge MN (2007) In vivo VEGF imaging with radiolabeled bevacizumab in a human ovarian tumor xenograft. J Nucl Med 48:1313-1319

116. Wang JQ, Miller KD, Sledge GW, Zheng QH (2005) Synthesis of [18F]SU11248, a new potential PET tracer for imaging cancer tyrosine kinase. Bioorg Med Chem Lett 15:4380-4384

117. Nagengast WB, De Korte MA, Oude Munnink TH, TimmerBosscha H, Den Dunnen WF, Hollema H, De Jong JR, Jensen MR, Quadt C, Garcia-Echeverria C, Van Dongen GA, Lub-de Hooge MN, Schroder CP, De Vries EG (2010) 89Zr-bevacizumab PET of early antiangiogenic tumor response to treatment with HSP90 inhibitor NVP-AUY922. J Nucl Med 51:761-767

118. Bex A, Horenblas S, Meinhardt W, Verra N, De Gast GC (2002) The role of initial immunotherapy as selection for nephrectomy in patients with metastatic renal cell carcinoma and the primary tumor in situ. Eur Urol 42:570-574

119. Bex A, Kerst M, Mallo H, Meinhardt W, Horenblas S, De Gast GC (2006) Interferon alpha $2 b$ as medical selection for nephrectomy in patients with synchronous metastatic renal cell carcinoma: a consecutive study. Eur Urol 49:76-81

120. Sella A, Swanson DA, Ro JY, Putnam JB Jr, Amato RJ, Markowitz AB, Logothetis CJ (1993) Surgery following response to interferon-alpha-based therapy for residual renal cell carcinoma. J Urol 149:19-21

121. Flanigan RC, Salmon SE, Blumenstein BA, Bearman SI, Roy V, McGrath PC, Caton JR Jr, Munshi N, Crawford ED (2001) Nephrectomy followed by interferon alfa- $2 b$ compared with interferon alfa- $2 \mathrm{~b}$ alone for metastatic renal-cell cancer. $\mathrm{N}$ Engl $\mathrm{J}$ Med 345:1655-1659

122. Flanigan RC, Mickisch G, Sylvester R, Tangen C, Van Poppel H, Crawford ED (2004) Cytoreductive nephrectomy in patients with metastatic renal cancer: a combined analysis. J Urol 171:10711076

123. Mickisch GH, Garin A, Van Poppel H, de Prijck L, Sylvester R (2001) Radical nephrectomy plus interferon-alfa-based immunotherapy compared with interferon alfa alone in metastatic renalcell carcinoma: a randomised trial. Lancet 358:966-970

124. Biswas S, Kelly J, Eisen T (2009) Cytoreductive nephrectomy in metastatic clear-cell renal cell carcinoma: perspectives in the tyrosine kinase inhibitor era. Oncologist 14:52-59

125. Bex A, Van der Veldt AA, Blank C, Van den Eertwegh AJ, Boven E, Horenblas S, Haanen J (2009) Neoadjuvant sunitinib for surgically complex advanced renal cell cancer of doubtful resectability: initial experience with downsizing to reconsider cytoreductive surgery. World J Urol 27:533-539

126. Cowey CL, Amin C, Pruthi RS, Wallen EM, Nielsen ME, Grigson G, Watkins C, Nance KV, Crane J, Jalkut M, Moore DT, Kim WY, Godley PA, Whang YE, Fielding JR, Rathmell WK (2010) Neoadjuvant clinical trial with sorafenib for patients with stage II or higher renal cell carcinoma. J Clin Oncol 28:1502-1507

127. Amin C, Wallen E, Pruthi RS, Calvo BF, Godley PA, Rathmell WK (2008) Preoperative tyrosine kinase inhibition as an adjunct to debulking nephrectomy. Urology 72:864-868

128. Thomas AA, Rini BI, Lane BR, Garcia J, Dreicer R, Klein EA, Novick AC, Campbell SC (2009) Response of the primary tumor to neoadjuvant sunitinib in patients with advanced renal cell carcinoma. J Urol 181:518-523

129. Bex A, Van der Veldt AA, Blank C, Meijerink MR, Boven E, Haanen JB (2010) Progression of a caval vein thrombus in two patients with primary renal cell carcinoma on pretreatment with sunitinib. Acta Oncol 49:520-523

130. Kunkle DA, Crispen PL, Li T, Uzzo RG (2007) Tumor size predicts synchronous metastatic renal cell carcinoma: implications for surveillance of small renal masses. J Urol 177:1692-1697 
131. Schwartz LH, Mazumdar M, Wang L, Smith A, Marion S, Panicek DM, Motzer RJ (2003) Response assessment classification in patients with advanced renal cell carcinoma treated on clinical trials. Cancer 98:1611-1619

132. Van der Veldt AA, Boven E, Bex A (2009) Re: Response of the primary tumor to neoadjuvant sunitinib in patients with advanced renal cell carcinoma. A. A. Thomas, B. I. Rini, B. R. Lane, J. Garcia, R. Dreicer, E. A. Klein, A. C. Novick And S. C. Campbell. J Urol 2009; 181: 518-523. J Urol 182:797-798

133. Jonasch E, Wood CG, Matin SF, Tu SM, Pagliaro LC, Corn PG, Aparicio A, Tamboli P, Millikan RE, Wang X, Araujo JC, Arap W, Tannir N (2009) Phase II presurgical feasibility study of bevacizumab in untreated patients with metastatic renal cell carcinoma. J Clin Oncol 27:4076-4081

134. Cowey CL, Fielding JR, Kimryn Rathmell W (2009) The loss of radiographic enhancement in primary renal cell carcinoma tumors following multitargeted receptor tyrosine kinase therapy is an additional indicator of response. Urology 75:11081113

135. Motzer RJ, Nanus DM, Russo P, Berg WJ (2007) Renal cell carcinoma. Curr Probl Cancer 21:185-232

136. Blumenschein GR Jr, Gatzemeier U, Fossella F, Stewart DJ, Cupit L, Cihon F, O'Leary J, Reck M (2009) Phase II, multicenter, uncontrolled trial of single-agent sorafenib in patients with relapsed or refractory, advanced non-small-cell lung cancer. J Clin Oncol 27:4274-4280

137. Crabb SJ, Patsios D, Sauerbrei E, Ellis PM, Arnold A, Goss G, Leighl NB, Shepherd FA, Powers J, Seymour L, Laurie SA (2009) Tumor cavitation: impact on objective response evaluation in trials of angiogenesis inhibitors in non-small-cell lung cancer. J Clin Oncol 27:404-410

138. Zolnierek J, Nurzynski P, Langiewicz P, Oborska S, WaskoGrabowska A, Kuszatal E, Obrocka B, Szczylik C (2010) Efficacy of targeted therapy in patients with renal cell carcinoma with pre-existing or new bone metastases. J Cancer Res Clin Oncol 136:371-378

139. Wu HC, Yen RF, Shen YY, Kao CH, Lin CC, Lee CC (2002) Comparing whole body 18F-2-deoxyglucose positron emission tomography and technetium- $99 \mathrm{~m}$ methylene diphosphate bone scan to detect bone metastases in patients with renal cell carcinomas - a preliminary report. J Cancer Res Clin Oncol 128:503-506

140. Bauerle T, Semmler W (2009) Imaging response to systemic therapy for bone metastases. Eur Radiol 19:2495-2507

141. Schellinger PD, Meinck HM, Thron A (1999) Diagnostic accuracy of MRI compared to CCT in patients with brain metastases. J Neurooncol 44:275-281

142. Helgason HH, Mallo HA, Droogendijk H, Haanen J, Van der Veldt AA, Van den Eertwegh AJ, Boven E (2008) Brain metastases in patients with renal cell cancer receiving new targeted treatment. J Clin Oncol 26:152-154
143. Koutras AK, Krikelis D, Alexandrou N, Starakis I, Kalofonos HP (2007) Brain metastasis in renal cell cancer responding to sunitinib. Anticancer Res 27:4255-4257

144. Medioni J, Cojocarasu O, Belcaceres JL, Halimi P, Oudard S (2007) Complete cerebral response with sunitinib for metastatic renal cell carcinoma. Ann Oncol 18:1282-1283

145. Valcamonico F, Ferrari V, Amoroso V, Rangoni G, Simoncini E, Marpicati P, Vassalli L, Grisanti S, Marini G (2009) Long-lasting successful cerebral response with sorafenib in advanced renal cell carcinoma. J Neurooncol 91:47-50

146. Zeng H, Li X, Yao J, Zhu Y, Liu J, Yang Y, Qiang W (2009) Multifocal brain metastases in clear cell renal cell carcinoma with complete response to sunitinib. Urol Int 83:482-485

147. Hill KL Jr, Lipson AC, Sheehan JM (2009) Brain magnetic resonance imaging changes after sorafenib and sunitinib chemotherapy in patients with advanced renal cell and breast carcinoma. J Neurosurg 111:497-503

148. Batchelor TT, Sorensen AG, Di Tomaso E, Zhang WT, Duda DG, Cohen KS, Kozak KR, Cahill DP, Chen PJ, Zhu M, Ancukiewicz M, Mrugala MM, Plotkin S, Drappatz J, Louis DN, Ivy P, Scadden DT, Benner T, Loeffler JS, Wen PY, Jain RK (2007) AZD2171, a pan-VEGF receptor tyrosine kinase inhibitor, normalizes tumor vasculature and alleviates edema in glioblastoma patients. Cancer Cell 11:83-95

149. Hillman SL, An MW, O'Connell MJ, Goldberg RM, Schaefer P, Buckner JC, Sargent DJ (2009) Evaluation of the optimal number of lesions needed for tumor evaluation using the response evaluation criteria in solid tumors: a North Central Cancer Treatment Group Investigation. J Clin Oncol 27:3205-3210

150. Sica DA (2006) Angiogenesis inhibitors and hypertension: an emerging issue. J Clin Oncol 24:1329-1331

151. Van der Veldt AA, Boven E, Vroling L, Broxterman HJ, Van den Eertwegh AJ, Haanen JG (2009) Sunitinib-induced hemoglobin changes are related to the dosing schedule. J Clin Oncol 27:1339-1340

152. Azizi M, Chedid A, Oudard S (2008) Home blood-pressure monitoring in patients receiving sunitinib. N Engl J Med 358:95-97

153. Van der Veldt AA, De Boer MP, Boven E, Eringa EC, Van den Eertwegh AJ, Van Hinsbergh VW, Smulders YM, Serne EH (2010) Reduction in skin microvascular density and changes in vessel morphology in patients treated with sunitinib. Anticancer Drugs 21:439-446

154. Van der Veldt AA, Boven E, Helgason HH, Van Wouwe M, Berkhof J, De Gast G, Mallo H, Tillier CN, Van den Eertwegh AJ, Haanen JB (2008) Predictive factors for severe toxicity of sunitinib in unselected patients with advanced renal cell cancer. Br J Cancer 99:259-265

155. Desar IM, Mulder SF, Stillebroer AB, Van Spronsen DJ, Van der Graaf WT, Mulders PFA, Van Herpen CM (2009) The reverse side of the victory: flare up of symptoms after discontinuation of sunitinib or sorafenib in renal cell cancer patients. A report of three cases. Acta Oncol 48:927-931 